\title{
Pathophysiology of the choroid plexus in brain diseases
}

\author{
Sandra Mihaljevic ${ }^{1,2}$, Alena Michalicova ${ }^{1}$, Mangesh Bhide ${ }^{2}$ and Andrej $\operatorname{Kovac}^{1}$ (D) \\ ${ }^{1}$ Institute of Neuroimmunology, Slovak Academy of Sciences, Bratislava, Slovakia \\ ${ }^{2}$ Laboratory of Biomedical Microbiology and Immunology, The University of Veterinary Medicine and Pharmacy in Kosice, \\ Kosice, Slovakia
}

\begin{abstract}
The choroid plexus, located in the ventricular system of the central nervous system (CNS), obtains numerous roles critical for the proper development and operating of the CNS. The functions range from the best-known ones of the barrier and cerebrospinal fluid (CSF) producer, through participation in immune answer, 'nourishment, detoxification and reparation of the rest of the CNS. Increase number of studies point out the association between choroid plexus dysfunction, characterized by alterations in secretory, transport and barrier capabilities, and the broad spectrum of clinical conditions, as well as physiological aging. We present a brief overview of pathological states known or speculated to be connected to choroid plexus dysfunction, ranging from neurodevelopmental, to autoimmune and neurodegenerative diseases. We also cover the topic of choroid plexus tumors, as well explained involvement of the choroid plexus in pathogen invasion of the CNS, also referring to the currently actual SARS-CoV-2 infection. Finally, we have also touched conducted studies on the choroid plexus regenerative potential. With the information provided in the review we want to point out the importance and call for further research on the role of the choroid plexus in the sustainability of central nervous system health.
\end{abstract}

\begin{abstract}
Abbreviations: $\mathrm{A} \beta$, amyloid beta; $\mathrm{AD}$, Alzheimer's disease; $\mathrm{BBB}$, blood-brain barrier; $\mathrm{BCSFB}$, bloodcerebrospinal fluid barrier; $\mathrm{CP}$, choroid plexus; $\mathrm{CPECs}$, choroid plexus epithelial cells; $\mathrm{CPe}$, choroid plexus epithelium; CSF, cerebrospinal fluid; ICP, intracranial pressure; LPS, lipopolysaccharide; MMP, matrix metalloproteinase; NO, nitric oxide; TJs, tight junctions.
\end{abstract}

\section{Introduction}

The choroid plexus (CP) is a dynamic, highly vascularized secretory structure present in all four ventricles of the brain (i.e. laterals, third, and fourth), and thus strategically located to connect the peripheral blood circulation and the central nervous system (CNS) (Lun et al. 2015; Simon and Iliff 2016). The CP obtains multiple functions, essential for the maintenance of the CNS' proper functioning and homeostasis (Redzic and Segal 2004; Ghersi-Egea et al. 2018; Johanson 2018).

Correspondence to: Andrej Kovac, Institute of Neuroimmunology, Slovak Academy of Sciences, Dubravska cesta 9, 84510 Bratislava, Slovakia

E-mail: andrej.kovac@savba.sk
The tissue is composed of vessels penetrating stroma, surrounded by a single layer of cuboidal choroid plexus epithelial cells (CPECs), forming choroid plexus epithelium (CPe) (Emerich et al. 2005; Simon and Iliff 2016). The CPECs are tightly sealed by tight junctions into the blood-cerebrospinal fluid barrier (BCSFB). The BCSFB, together with anatomically similar blood-brain barrier (BBB), situated at the level of cerebrovascular endothelium, prevents the free paracellular entrance of blood-borne substances (Redzic 2011; Lauer et al. 2017), and thus supports the maintenance of the brain's milieu. Unlike in the BBB, endothelium of the CP is fenestrated (Wolburg and Paulus 2010; Lun et al. 2015; Simon and Iliff 2016), representing an important physiological basis for the CSF production (Cserr et al. 1992; Lun et al. 2015), as enabling ion and water transport (Fig. 1). The permeability

(C) The Authors 2021. This is an open access article under the terms of the Creative Commons Attribution-NonCommercial 4.0 International License (https://creativecommons.org/licenses/by-nc/4.0/), which permits non-commercial use, distribution, and reproduction in any medium, provided the original work is properly cited. 
of the layer is modulated by surrounding pericytes (Saul et al. 2020). Both layers, the CP endothelium and epithelium, lay on the basal lamina (Wolburg and Paulus 2010). It is proposed that this extracellular matrix play an important part in the organization and maintenance of the BCSFB integrity (Vandenbroucke et al. 2012).

The CPECs have an apical border (i.e. formed of microvilli and incorporated cilia) and basolateral interdigitations (i.e. in some publications referred to as basolateral labyrinth), significantly increasing the surface of the tissue and creating polarity of the layer (Lauer et al. 2017). Cilia support the CSF movement (Narita and Takeda 2015). Large mitochondrial content supports extensive transport and secretion properties of the CP (Spector et al. 2015). Under normal conditions, the mature CPECs do not undergo replacement or degeneration (Liddelow et al. 2010). The CPECs share the same origin with ependymal cells, lining the CSF-filled ventricular space (Wolburg and Paulus 2010)

Tight junctions (TJs), adherens junctions, and gap junctions are protein junctional complexes participating in the establishment of cell-cell adhesion and functional BCSFB within the CPe (Tietz and Engelhardt 2015; Solár et al. 2020b). Among these three groups, the TJs are located the most apically, and include occludin, claudins, and junctional adhesion molecules (JAMs). Their apical distribution is maintained through interactions with the actin cytoskeleton (Campos et al. 2016). Claudins reported in the CPe are Clauidn-1,-2,-3,-11 (Wolburg et al. 2001; Steinemann et al. 2016). TJs are prone to degradation by the activities of matrix metalloproteinases, probably infringing barrier integrity (Kirchner et al. 2000; Yang et al. 2007). The BCSFB shows functionality already in the early developmental stages (Dziegielewska et al. 1979; Møllgård et al. 1979).

The CP is 'the number one' CSF producer (Cserr et al. 1992; Redzic et al. 2005), while the sources of rest, with still poorly defined contribution, are brain interstitial fluid, ependyma and capillaries (Sakka et al. 2011). The CSF production at the $\mathrm{CP}$ is occurring through a series of wellorganised transfers of water and ions via bidirectionally deployed transporters on the CPs. Such polarized distribu-

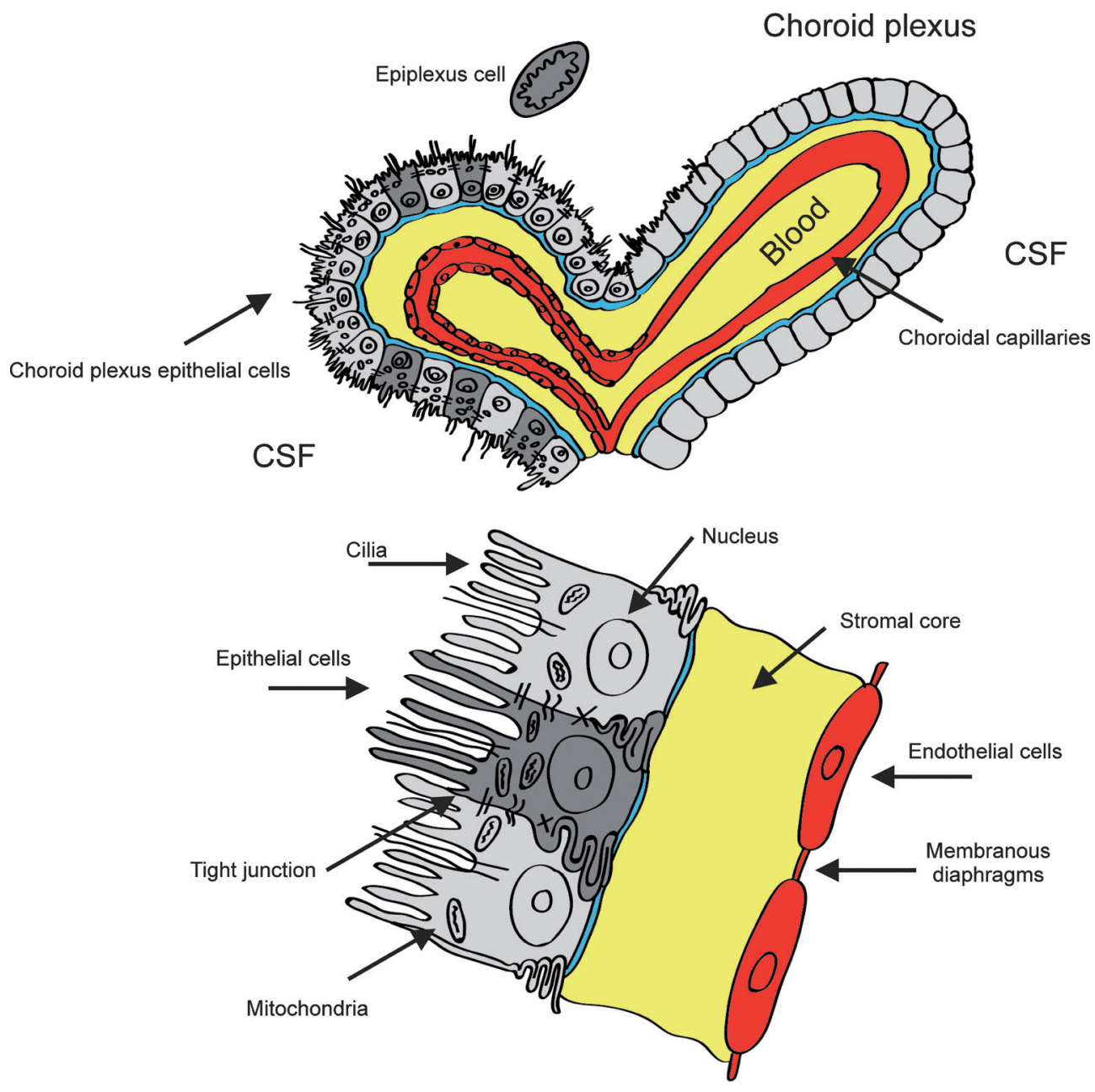

Figure 1. Structure of the choroid plexus. The choroid plexus is a highly vascularized secretory structure present in all four ventricles of the brain. The tissue comprises vessels penetrating stromal space, surrounded by a single layer of cuboidal choroid plexus epithelial cells (upper panel). Tight junctions tightly seal the choroid plexus epithelial cells (CPEC) into the bloodcerebrospinal fluid (CSF) barrier. The monolayer of CPEC surrounds the stromal core and capillaries. In contrast to the brain's parenchyma, the capillaries of the choroid plexus are fenestrated. The individual endothelial cells are connected by thin membranous diaphragms that are permeable to small molecules and water (bottom panel). 
tion of transporters is defined and supported by specific cytoskeleton arrangements (Damkier et al. 2013). By traditional theories of the CSF dynamics, the CSF produced in the ventricles, further enters and circulates in subarachnoid space surrounding the brain and spinal cord, where it gets reabsorbed into venous blood (Redzic and Segal 2004; Lun et al. 2015; Simon and Iliff 2016; Bothwell et al. 2019). These theories are expended with new knowledge about the existence of the glymphatic system within the brain parenchyma, in which the CSF that has exited subventricular circulation, further picks up the waste products from brain tissue, that are being drained into the lymphatic system (Verkhratsky et al. 2015). Circulating around the brain, the CSF mechanically protects it, and also helps in the maintenance of the normal intracranial pressure (Spector et al. 2015). Additionally, via the CSF, the CP 'nourishes' the brain with vital components for its development and maintenance in adulthood, that is being produced by the tissue itself, or transported across it (Emerich et al. 2005; Lehtinen et al. 2013; Johanson 2018). Although being filtrates of plasma, these two bodily fluids differ in $\mathrm{pH}$, the concentration of protein, amino acids, and ions (Damkier et al. 2013; Hladky and Barrand 2014). The CP tightly regulates the CSF composition, and physiological rates of production (Nilsson et al. 1994; Sakka et al. 2011; Damkier et al. 2013; Spector et al. 2015; Pardridge 2016), and their changes are usually associated with neurological states and the CP's dysfunction (Reiber 1994, 1995; Simon and Iliff 2016). For example, disruption of the CP barrier leads to leakage of the unwanted proteins from plasma osmotically followed by water influx, changes in the regional CSF flow, inflammation and neural damage, especially affecting subventricular regions, i.e. hippocampus (Johanson 2018).

Acting as the immune gate, the $\mathrm{CP}$ very actively participates in the establishment of the immune response within the CNS in health and disease (Engelhardt and Ransohoff 2012; Ghersi-Egea et al. 2018). CP stroma harbours macrophages and dendritic cells, while on the CSF-facing surface are attached Kolmer's epiplexus cells, all being attributed with antigen-presenting properties (Lauer et al. 2017). During neuroinflammation, the $\mathrm{CP}$ serves as a niche for $\mathrm{T}$ cell infiltration. Inside the CP's stroma, being presented with antigen by APCs, CD4+ T cells undergo activation and proliferation, and further shape CNS response (Strominger et al. 2018). The stimulus can upregulate the expression of chemokines in the CPECs. As the first line of the CNS defence, the BCSFB properties, as well as the proinflammatory and anti-inflammatory profile of the tissue, change upon peripheral inflammatory insult (Emerich et al. 2005; Marques et al. 2009).

The CP and the CSF perform a significant role in the detoxification of the brain from metabolic wastes, potentially toxic compounds, and drugs. The $\mathrm{CP}$ owns a mechanism for impeding entrance and bio-distribution of noxious compounds and drugs within the brain via its machinery of metabolizing enzymes (Ghersi-Egea and Strazielle 2001; Crossgrove et al. 2005; Iliff et al. 2012).

Besides neurogenic capabilities of the CP tissue itself (Itokazu et al. 2006; Prasongchean et al. 2015), the CP might support neurogenesis of the other parts of the CNS as well, through secretion of various neurotrophic factors (Borlongan Cesar et al. 2004). So for example, by 'tuning' the CSF composition, the CP affects properties of the subventricular zone, an important neural source of the adult brain (Falcao et al. 2012).

\section{Systemic inflammation}

Experimentally, systemic inflammation is usually provoked by intravenous/intraperitoneal injection of LPS (Dickson and Lehmann 2019; Solár et al. 2020b). Response to this peripheral stimulus in the CP includes changes in anti- and pro-inflammatory profiles, down-regulation of TJ proteins, and proteins of extracellular matrix involved in cell-to-cell interactions, indicating the BCSFB destruction. In response to the adverse effect of proteases and matrix metalloproteinases (MMPs), which are likely to occur in the midst of barrier damage, increase production of inhibitor metalloproteinase 1 was observed at the $\mathrm{CP}$, as a possible protective mechanism of the CP for tissue itself (Flannery 2006; Marques et al. 2009; Dickson and Lehmann 2019). Additionally, lipocalin 2, a protein whose bacteriostatic effects have been shown in vitro and in vivo, has found to be upregulated for $72 \mathrm{~h}$ during acute infection in the $\mathrm{CP}$, and so likely, the $\mathrm{CP}$ also protects the rest of the brain from spreading of infection (Marques et al. 2009).

Systemic inflammatory syndrome, is a highly mortal systemic inflammatory condition, significantly effecting the brain. The depletion or inhibition of MMP8 has a protective effect from death and neurological complications of the disease, probably through the prevention of BCSFB leakage correlating with increase CSF cytokine levels, brain inflammation, and downregulation of the brain glucocorticoid receptor (Vandenbroucke et al. 2012) . A similar effect of broad-spectrum of MMP inhibitors was also shown in vitro (Zeni et al. 2007).

\section{Aging, Alzheimer's disease and other neurodegenera- tive disorders}

Changes in the neurovascular unit are well described (Zlokovic 2008; Sweeney et al. 2018). In addition, there is a growing number of studies indicating that morphological and functional alterations of the $\mathrm{CP}$ play a significant role in the pathology and progression of neurodegenerative disorders, as well as in physiological aging. Alzheimer's disease (AD), 
the most common form of dementia, is histopathologically characterized by extracellular amyloid plaques (formed of $\mathrm{A} \beta$ peptides), and intracellular neurofibrillary tangles, formed of microtubule-associated tau protein (Balusu et al. 2016; Kent et al. 2020; Alzheimer's Association 2021). Their presence has been driven into connection with progressive cognitive decline and brain atrophy, and decreased CSF turnover (Nelson et al. 2009; Smolek et al. 2016; Mormino and Papp 2018; Attier-Zmudka et al. 2019; Jadhav et al. 2019).

Already in 1997, Hampel and colleagues speculated that alterations of the BCSFB may contribute to AD pathology (Hampel et al. 1997). The pattern of morphological and functional changes of the BCSFB in aging and $\mathrm{AD}$ is very similar, but significantly accelerated in the latter, which to some extend supports the theory of $\mathrm{AD}$ as 'amplified senescence' (West et al. 1997), therefore, through the chapter, they will be discussed in parallel. At the level of epithelium, there is cell flattening, along with the shortening of microvilli, irregular shaping of nuclei and common presence of lipid vacuoles (Serot et al. 2001; Kaur et al. 2016). Underneath the epithelium, the basal membrane gets thicker too, as well as tissue stroma, while the basal membrane of endothelium is seen moderately increased and becomes fragmented (Preston 2001; Serot et al. 2001; Emerich et al. 2005). In the cytoplasm of the CPECs can be observed inclusions such as Biondi bodies (Kiktenko 1986; Wen et al. 1999; Balusu et al. 2016); psammoma bodies (Wen et al. 1999; Jovanović et al. 2010; Raha-Chowdhury et al. 2019), and lipofuscin (Wen et al. 1999; Krzyzanowska and Carro 2012).

An increase of nitric oxide (NO) levels interferes with immune cell trafficking across the BCSFB (Baruch et al. 2015); and immune gate function can be restored by implementing NO scavengers through induction of the $\mathrm{NF}_{\mathrm{k}} \mathrm{B} / \mathrm{p} 65$ pathway. Analyses of autopsied CP showed increased levels of heat shock protein HSP90 (Johanson et al. 2004). Disruption of the barrier may occur even before the development of $\mathrm{AD}$ pathology, as based on measurements of CSF/serum albumin ratio and CSF secretory $\mathrm{Ca}^{2+}$-dependent phospholipase A2 activity (Chalbot et al. 2011).

Characteristic increased $A \beta$ levels in the CSF in $A D$, whose presence has been linked to cognitive decline (Wu et al. 2016), probably come as a result of an imbalance between production and clearance of $\mathrm{A} \beta$ peptides (Hardy and Selkoe 2002; Mawuenyega et al. 2010). There is also a load of these peptides in the CPECs, probably resulting in decreased CSF production and $A \beta$ clearance leading to upregulation of pro-inflammatory molecules (IL1, IL6, TNFa and iNOS) and increased levels of MMPs, that both may lead to barrier alterations (Eriksson and Westermark 1986; Dietrich et al. 2008; Wolburg and Paulus 2010; González-Marrero et al. 2015; Brkic et al. 2015b). It is speculated that mitochondrial dysfunction present in the AD CP, may be attributed at least partly to $\mathrm{A} \beta$ overload within the tissue (Krzyzanowska and
Carro 2012). Furthermore, toxic A $\beta$ load can be caused by down-regulation of proteins involved in $A \beta$ peptide clearance, like transthyretin (Serot et al. 1997; Chen et al. 2005; Van Cauwenberghe et al. 2020), megalin (Carro et al. 2005; Alvira-Botero and Carro 2010), and clusterin (Zlokovic et al. 1996), as observed in AD. Removal of $A \beta$ peptides from the CNS happens through the joined actions of the brain barriers, who share the common transporters for this peptide, but can show different expression profiles in the disease. In $\mathrm{AD}$, the expression of efflux transporter lipoprotein receptor-related protein 1 in the $\mathrm{CP}$ is upregulated, while influx transporter lipoprotein receptor-related protein 2 is downregulated, which is in contrast to changes observed on the $\mathrm{BBB}$, indicating coordinated clearance activities between barriers, and that the BCSFB may serve as potential back-up mechanism of the BBB malfunctioning (Pascale et al. 2011). Levels of LPS, are present in aging and $\mathrm{AD}$, and co-localize with amyloid plaques (Zhan et al. 2018). Interestingly, the A $\beta$ burden exists in $20 \%$ cognitively normal individuals (Rodrigue et al. 2012).

Besides a decrease in clearance potential creating toxic protein load, changes in the structural integrity of the CP probably lead to the decrease of secretory activities and diminished brain supply with necessary compounds. Alterations in the expression of genes involved in CSF production have been reported in AD patients (Kant et al. 2018). Abnormalities in the CSF secretion and turnover have been observed in human and animal models of aging (Silverberg et al. 2001; Redzic et al. 2005). The estimated $0.2 \mathrm{ml} / \mathrm{h}$ level of CSF production in AD patients, is remarkably lower than the normal rate (Silverberg et al. 2010). In AD, there is an increase in vasopressin binding sites on the $\mathrm{CP}$, which can decrease blood flow into the CP and reduce the CSF production (Faraci et al. 1990; Korting et al. 1996).

Both aging and neurodegenerative disorders are of inflammatory nature (Tarkowski et al. 2003; Simen et al. 2011; Zilka et al. 2012; Brkic et al. 2015a; Kinney et al. 2018). Baruch et al. (2014) showed that the CP expresses a unique 'aging signature', mainly through the type I interferon signalling by IFN- $\gamma$, that chronically upregulates in aging. Blocking of this pathway resulted in partial restoration of aging-disturbed cognition and hippocampal neurogenesis. Interplay, which is a diverse pattern of changes in the expression of INF-I and INF-II signalling, observed in aging and $\mathrm{AD}$, maybe a potential therapeutic target to slow aging and prevent $\mathrm{AD}$ (Baruch et al. 2014; Mesquita et al.2015). Additionally, the CP has high expression of the KLOTHO gene, coding for 'anti-aging' hormone present in the blood and the CSF, that has shown effects against $\mathrm{AD}$ pathology and cognitive impairment (Liddelow 2015; Zeng et al. 2019). AD patients have decreased levels of this hormone in their CSF (Semba et al. 2014). Ott et al. (2010) examined the relationship between changes in ventricular volumetry and CSF biomarkers in mild-cognitive impaired 
and $\mathrm{AD}$ patients. Although, they found a strong relationship between $A \beta$ levels and neuropathology of $A D$, characterized also with hydrocephalic enlargement, the relation between volumetric changes and the CSF biomarkers was not significant, and authors debate that possible reasons for the results might 'hide' in alterations of the brain barriers and decrease of the CSF production with aging and in neurodegeneration.

The hallmark of the second most common neurodegenerative disorder, Parkinson's disease (PD), is pathological $\alpha$-synuclein ( $\alpha-S y n)$. The $\alpha$-Syn accumulates and aggregates, disturbing synaptic functionality and mitochondrial energy production, which is manifested in motor impairment and cognitive decline (Bates and Zheng 2014; Bridi and Hirth 2018). There is still a rather scarce number of studies on the connectivity between the BCSFB functioning/alterations and neurodegeneration in PD. Bates et al. (2015) showed that $\alpha$-Syn can be transported via the BSFB monolayer, and that there is a significant increase of $\alpha$-Syn uptake by the CPECs after exposure to manganese (i.e. toxic metal implicated in PD onset). Increased albumin transfer via the BCSFB that occurs in advanced stages of the disease, indicates the barrier's disruption (Pisani et al. 2012). The effect of neurotrophins derived from encapsulated porcine CPECs (termed NTCELL) considered to be a promising regenerative treatment option in $\mathrm{PD}$, is still under testing for efficiency, but the phase II study, did not show improvement in tested subjects (Snow et al. 2019). Very similarly, encapsulated rat CP cells were tested for regenerative treatment in another neurodegenerative disorder, Huntington disease (HD), but here the transplants showed a neuroprotective effect, with variations among different neuronal populations (Borlongan et al. 2007). Genomic studies of post-mortem CP isolates revealed up-regulation of cadherin and down-regulation of Cl-5 in this disease group patients (Stopa et al. 2018).

Amyotrophic lateral sclerosis (ALS) is a neurodegenerative disease affecting mostly motor neurons, especially the one of the brain and spinal cord, in which improper accumulation of neurofilaments occurs (Smith et al. 2015; Saul et al. 2020). Potential mechanisms of disease spread are neuroanatomical propagation and the factors circulating the CSF (Ravits 2014; Smith et al. 2015). Significant increase of total protein (Leonardi et al. 1984) and complement component $3 c$ concentrations (Annunziata and Volpi 1985) correlating to the CSF albumin/serum albumin ratio, as well as an increase of blood-borne substances (Donnenfeld et al. 1984) in the CSF of ALS patients indicate probable barriers disruption (Garbuzova-Davis and Sanberg 2014). The CP probably fails to help in fighting inflammation present in disease, as the mouse model of ALS (mutant SOD1 ${ }^{\mathrm{G} 93 \mathrm{~A}}$ ) and shows the decrease in IFN- $\gamma$ singling needed for CD4+ recruitment via the CP (Kunis et al. 2015). Saul et al. (2020) have reported a wide range of histopathological and transcriptomic changes in post-mortem CPs of ALS patients evident through alteration/downregulation of tight junctional proteins, and mislocation and/or overall or regional loss of some of them, as well as probable disruption of vascular integrity (i.e. downregulation and discontinuous expression of CD31) and pericytes reduction around the vessels. These $\mathrm{CP}$ alterations may result in decreased clearance potential and previously mentioned changes in the CSF composition. An increase number of macrophages, C-reactive protein (CRP) and MerTK receptor tyrosine kinase positive cells, witness ongoing inflammation and apoptosis in the tissue. Interestingly, expression of measured MMPs was downregulated.

\section{Hydrocephalus and the $\mathrm{CP}$ tumors}

\section{Hydrocephalus}

Hydrocephalus is a condition characterized by ventricular enlargement (i.e. ventriculomegaly), increased CSF volume and usually intracranial pressure, that in the case untreated, can be life-threatening (Grote and Hassler 1988; Liptak 2007; Kahle et al. 2016; Karimy et al. 2016). Still, correlations between the intracranial pressure (ICP) and CSF formation in hydrocephalus can vary (Calhoun et al. 1967; Lorenzo et al. 1970). Division of the disease made by Damkier et al. (2013), classifies it based on time of appearance throughout life (i.e. infantile, juvenile, adult forms), the effect on ICP (i.e. high- and normal-pressure), the way of CSF flow, that is if there is a free flow from ventricles towards subarachnoid space (i.e. communicating and noncommunicating form), and progression of the disease (i.e. active and arrested form).

The disease arises due to some kind of perturbation in regular CSF flow that is either result of its obstruction, increase, or decrease in the CSF flow (Oi 2011) and can be caused by a variety of disorders like, infections, tumors, hemorrhage, and strokes (Krishnamurthy and Li 2014) leading to further clinical complications.

Morphological-functional effects of hydrocephalus on the CP tissue include atrophy of epithelium, reduction in number, as well as shortening and swelling of microvilli, sclerotic stroma, dilatation of intracellular spaces and of basolateral interdigitations (Shuangshoti et al. 1965; Madhavi and Jacob 1995; Owler et al. 2010). Intercellular junctions seem to be preserved (Tirapelli et al. 2007). The changes are accompanied by infestation and the increase of various types of immune cells (Go et al. 1976; Lu et al. 1996; Solár et al. 2020a). The rate of proliferation increases . Also, mutations in $M p d z$, one of only eight genes associated with heritable hydrocephalus, coding for eight junctional proteins, are associated with pronounced permeability of the BCSFB, and probably a subsequent enormous increase of the CSF protein 
concentration for even 53-folds (Yang et al. 2019). When ICP increased, seems that the CP has protective mechanisms for regulation of CSF flow to decrease the pressure (Knuckey et al. 1993; Faraci et al. 1994). Normally present diffused dispersion of aquaporin-4 in the cytoplasm of the CPECs (Speake et al. 2003), may allow reabsorption of water from the CSF back into capillaries and be the compensatory mechanism of the cell against hydrocephalus, while the relocation of AQP1 inside the cytoplasm, may be happening in the same goal (Speake et al. 2003; Owler et al. 2010). Dohrmann (1971) for the first time connected morphological changes in the $\mathrm{CP}$ with changes in the CSF pressure. In dogs with experimentally provoked hydrocephalus flattening and compacted cytoplasm of the CPECs were observed, as probable results of increased intraventricular pressure, and ventriculojugular shunt restored these morphological alterations already after one day of the procedure. Several groups have demonstrated that cilia defects at the CPECs can cause communicating hydrocephalus (Banizs et al. 2005; Wodarczyk et al. 2009; Tissir et al. 2010; Swiderski et al. 2012; Liu et al. 2014; Narita and Takeda 2015).

The ventricular shunt is still the predominant surgical treatment of hydrocephalus but also other treatments involving manipulations in the ventricular system have shown great success (Warf 2005, 2013; Norkett et al. 2016). Of pharmacological approaches, positive and promising results in a decrease of CSF production have come from the use of acetazolamide, an inhibitor of carbonic anhydrase and exendin-4 (Carrion et al. 2001; Ivkovic et al. 2015; Bothwell et al. 2019).

\section{CP tumors}

$\mathrm{CP}$ tumors, present as neuroepithelial neoplasms are rare, and mostly present in childhood accounting for $2-5 \%$ of brain tumors in children (Rickert and Paulus 2001; Merve et al. 2019). In that age group they are mostly found in lateral ventricles, and if occur in adulthood, they mostly affect the fourth ventricle (Hasselblatt et al. 2009; Lun et al. 2015). CP tumors can be divided into benign tumors, i.e. papillomas and carcinomas whose pathological findings range from well-preserved structures in both, papillomas and carcinomas, to severely disturbed tissue morphology ( $\mathrm{McComb}$ and Burger 1983). Still, certain differential markers for distinguishment between these two tumor types exist (Solár et al. 2020b). Also, carcinomas are characterized by loss of aquaporin-1 expression (Longatti et al. 2006). High expression of twist-related protein 1 in the CP papillomas, as well as glial fibrillary acidic protein in both tumor types (Rickert and Paulus 2001), indicates a high proliferation rate within disease tissue. The clinical picture often indicates hydrocephalus, accompanied by increased ICP (Rickert and Paulus 2001; Lin et al. 2019). Merve et al. (2019) have created a mice model of a human benign CP tumor with overexpression of $\mathrm{c}-\mathrm{Myc}$, the protein of the MYC family involved in numerous cell processes (i.e. proliferation, apoptosis, metabolism), and that is often overexpressed in tumors. The group has linked c-Myc overexpression with inflammation in the tissue, presented by increased infiltration of CD3+T-cells (i.e. especially CD4+T-helper cells) and CD68+ macrophages, opening the possibility of anti-inflammatory therapy of the CP tumors.

\section{Autoimmune disorders}

Studies on multiple sclerosis (MS), the most prevalent CNS inflammatory disease, characterized by inflammation, demyelination, and neurodegeneration, have provided many answers about brain-immune interactions (Vercellino et al. 2009; Martin et al. 2016). The clinical picture shows a brain with lesions, that have both infiltrations of helper (CD4+) and cytotoxic (CD8+) T cells (Reich et al. 2018), of which the first subtype significantly exceeds the number of the second indicating the central role that CD4+T cells hold in MS pathology (Rangachari and Kuchroo 2013). An experimental model of disease, experimental autoimmune encephalomyelitis (EAE) significantly affecting the $\mathrm{CP}$ morphology and provoking immunological answers in the CP epithelium and stroma (Frausto et al. 2007). During EAE, the CP shows upregulation of adhesion molecules, chemokines, statins, and interleukins, supporting infiltration of peripheral autoregressive immune cells (Engelhardt et al. 2001). VCAM-1 possibly plays a role in leukocyte transmigration in MS, as patients show VCAM-1 upregulation in the CPe (Vercellino et al. 2008). Murugesan et al. (2012) have analysed the difference of immune answers between the CP stromal capillary and the CP epithelium in response to $\mathrm{MOG}_{35-55}$ peptide immunization. While the stromal capillary showed increased expression of CCL5, CCL19, and the endothelium showed upregulation of C3, CXCL10, CCL19 and selectin. Both tissue constituents showed upregulation of Bm2 and C3. Also, the CSF of MS patients shows higher abundancy in immune cell content in comparison to control, indicating an increase immune cell crossing of the BCSB (Han et al. 2014).

IL-17 producing effector $\mathrm{T}$ helper cell subpopulation, Th17 cells, is associated with the onset of EAE (Korn et al. 2009). The cells gain access via the CP through chemokine receptor CCR 6 and chemokine ligand CCL20, constitutively expressed in the CPECs, that is being upregulated on IL-17 stimuli (Reboldi et al. 2009; Kaur et al. 2013). Kuwabara et al. (2017) speculated the importance of CCL19/ CCL21-CCR7 ligand in the generation of Th17 subset via IL-23, but it was later proved that initial differentiation of Th17 cells is mediated by cytokine combination of TGF- $\beta$ and IL-6 (Rangachari and Kuchroo 2013). The entrance 
of autoaggressive $\mathrm{T}$ cells further provokes characteristic demyelination and neuronal loss within the brain (Dixon and Pérez 2020).

Human post-mortem CP tissue studies showed a significant increase of CD4+ and CD8+ T cell populations and granulocytes (mostly neutrophiles) in MS patients, with a great abundancy of MHCII-expressing macrophages and DC cells (Rodríguez-Lorenzo et al. 2020).

As far as structural changes in the tissue during the disease, swelling of $\mathrm{CP}$ stromal capillaries probably as a result of increased capillary permeability (Murugesan et al. 2012) and changes at the level of microvilli, mitochondria and increase in 'dark' cell frequency were observed (Engelhardt et al. 2001). On the level of barrier, the latter group observed loss of immunoreactivity for $\mathrm{Cl}-1$ and $\mathrm{Cl}-2$, and weaker expression for Cl-11. Analyses of post-mortem brain tissues of MS patients revealed loss of Cl-3 (Kooij et al. 2014). Still, this does not necessarily lead to barrier impairment (Castro Dias et al. 2019).

Very late antigen (VLA-4; integrin $\alpha 4 \beta 1$ ) and melanoma cell adhesion molecule are important for transmigration of Thelper $\left(\mathrm{T}_{\mathrm{H}}\right) 1$ cell into the CNS in MS via endothelial layers. Blockade of melanoma cell adhesion molecule, whose ligand laminin 411 is expressed in the endothelium of the $\mathrm{CP}$, in combination with conditional ablation of a4-integrin on T cells, delayed disease onset (Breuer et al. 2018). One of the most effective MS drug treatments, natalizumab, prevents interaction between T cell VLA- $4\left(\alpha_{4} \beta_{1}\right.$ integrin $=$ CD49d/CD29, VCAM-1 ligand) and its receptors on brain endothelium and the CP (Ransohoff 2007; Alvarez et al. 2011; Schneider-Hohendorf et al. 2014). Interestingly, there is an upregulation of P-selectin after VLA-4 blockage, indicating that immune cells could use an alternative route for entering the CNS (Schneider-Hohendorf et al. 2014). The drug may downregulate the expression of lipocalin 2, present in the CP stroma, and thus, probably reduce neutrophil infiltration in the CNS (Marques et al. 2012).

Little is known about the involvement of the $\mathrm{CP}$ in other autoimmune conditions. Neuropsychiatric systemic lupus erythematosus (NPSLE) is an autoimmune disease characterized by neuropathic antibodies infiltration into the CSF, that is believed to occur via pathological brain barriers. Gelb et al. (2018) shifted focus on the BCSFB as the primary entry site of the antibodies provoking NPSLE, as they found no changes in integrity if the $\mathrm{BBB}$ in the disease, while their findings indicated probable dysfunction of the BCSFB.

\section{Pathogen invasion of the CNS via the CP}

Penetration via the CP to reach the CNS is the substantial mechanism of some viruses, bacteria, fungi, and parasites. Vessel fenestration, absence of glial limitans, and lower epithelial resistance are some of the reasons why pathogens choose the $\mathrm{CP}$ as a route of invasion. Three mechanisms used by pathogenic invaders for crossing the BCSFB have been described: transcellular (via pinocytosis or receptors), paracellular (via disturbed tight and adherents junctions), and 'Trojan horse' mechanism (pathogens enter tissue via infiltrating leukocytes) (Dando et al. 2014; Schwerk et al. 2015). After entering the CP, they infect the tissue and cause an inflammatory response. Some of the pathogens use it also as replication space. Invasion of pathogens into the CP may leave the barrier intact or cause its disruption.

\section{Viruses}

The CP serves as an entry and reproduction compartment of enterovirus, the viral cause of encephalitis, infection with the highest prevalence in children (Feuer et al. 2003; Schneider et al. 2012; Huang and Shih 2015). Usage of in vitro BCSFB model derived from human CP papilloma cells, showed that both, apical and basolateral sides of the $\mathrm{CPe}$ can be infected by the virus, and during 5 -h infection period cells remained viable and barrier showed no disruption (Schneider et al. 2012). Interestingly, the presence of the virus provoked increased chemokine expression (i.e. CXCL1, CXCL2 and CXCL3), but had no significance on $\mathrm{T}$ cells migration, as observed in vivo (Lucht et al. 1992). Infection with coxsackievirus B3 (CVB3) was monitored in neonatal mice using recombinant CVB3 expressing the enhanced green fluorescent protein. In early infection stages, the virus was found in high quantities in the $\mathrm{CP}$, also without indications of barrier disruption (Feuer et al. 2003) suggesting virus receptor-TJ binding mechanism of the entrance. In the CPECs of the same animal models was also found lymphocytic choriomeningitis virus (Puccini et al. 2014).

The CP is also believed to be the reservoir for human immunodeficiency virus (HIV), from where it probably disseminates to other brain areas (Falangola et al. 1995; Petito et al. 1999).

Severe acute respiratory syndrome coronavirus 2 (SARSCoV-2), causing the coronavirus disease 2019, primarily infecting respiratory track (Fotuhi et al. 2020), has also been connected with a wide range of neurological complications, like headache, dizziness, stroke, as well as encephalitis/meningitis (Mao et al. 2020; Montalvan et al. 2020; Moriguchi et al. 2020). Still, needs to be determined if the CNS complications arise from systemic inflammation, or from the viral invasion into the CNS. Possible involvement of the $\mathrm{CP}$ in any of these viral infecting mechanisms should be taken under serious consideration. Using organoids technology, Pellegrini et al. (2020) showed that SARS-CoV-2 spike protein pseudoand live-virus cause the $\mathrm{CP}$ infection, primarily within the $\mathrm{CPe}$, that expresses the ACE2 receptor. In addition, the same 
receptor was not expressed on neurons or neural progenitors, indicating the occurrence of the infection from blood facing side of the tissue. The same group also demonstrated a severe breakdown of the integrity of the BCSFB in presence of viral spike protein.

\section{Bacteria}

Haemophilus influenza type B (Hib), a known cause of bacterial meningitis in infants and children, whose occurrence has been significantly reduced by routine vaccination (Kim 2010), probably uses the CP as an entry route into the CNS. A study in infant primates, showed in early inflammatory phases the presence of $\mathrm{HiB}$ in ventricular spaces, while the CP showed histopathological alterations and immune response, indicating the tissue as an entry route of bacteria (Daum et al. 1978). Pathological changes observed in the $\mathrm{CP}$ include stromal plexitis, and severe necrosis, as a possible consequence of hydrocephalus, present in the disease (Smith 1987).

The host of Gram-positive agent Streptococcus suis (S. suis) is the pig, causing meningitis, sepsis and endocarditis (Staats et al. 1997). S. suis viral agents were histopathologically observed in the CP of these animals (Williams and Blakemore 1990; Madsen et al. 2002). Using inverted BCSFB cell cultivation model, derived from porcine choroid plexus epithelial cells (pCPECs), Wewer et al. (2011) studied transmigration of polymorphonuclear neutrophils (PMNs) through the barrier under inflammatory conditions caused by S. suis. Upon stimulation with zoonotic agent, the model showed a high transmigration rate of PMNs, joined with increase expression of adhesion molecules, and alterations in junctional and cytoskeleton organization, although no leukocyte passage through junctions was observed. The fluorescence imaging and electron microscopy revealed that PMNs pass via transcellular pathway using funnel-like structures on the apical portion of epithelium, while the transversal route seems to depend on CD11b/CD18 interactions. The CP has been recognized as a potential entry route of $S$. suis also in mice (Domínguez-Punaro et al. 2007). Important to note, the observations were recapitulated in the human HIBCPP model (Schwerk et al. 2012), proving reproducibility of animal model results in humans. The HIBCPP model was also successfully used for the study of bacterial invasion across the CP of Neisseria meningitidis (Borkowski et al. 2014), Listeria monocytogenes (Gründler et al. 2013) and Escherichia coli (E. coli) (Rose et al. 2018). Gram-negative bacteria $E$. coli, usually colonizing the intestinal tract, can also cause neonatal meningitis and E. coli meningitis (Rose et al. 2018). Neurological symptoms in acute ventriculitis sepsis caused by $E$. coli have been driven into connection with changes in the CP interface (Cardia et al. 1995).
Listeria monocytogenes causes choroiditis coupled with meningitis, while at the histological level there is ventricular space necrosis and immune cells extrusion into ventricular spaces (Prats et al. 1992).

There is currently exceeding research about the connection between gut microbiota, and neurological status and mental health (Foster 2013; Hsiao et al. 2013; De Vadder et al. 2014; Kelly et al. 2017). The brain and the BBB have been recognized as communicators within this gut-brain axis (Logsdon et al. 2018). Results showed that gut infection with Helicobacter suis, bacteria causes inflammation and disruption of the BCSFB in the mouse brain, while the BBB remained intact (Gorlé et al. 2018).

\section{Fungi}

Cryptococcus neoformans (C. neoformans) is quite a common CNS fungal infector, as the CSF is free of antycryptococcocal factors, and is usually provoking meningitis (Kumari et al. 2010). To the infection are particularly susceptible immunosuppressed individuals. Studies confirm interaction and passing of fungi though the BBB, and this is by general believe, the route of fungal entrance into the CNS (Chang et al. 2004; Jong et al. 2008; Huang et al. 2012; Tseng et al. 2015). Clinical image of two case reports of the CP plexitis caused by infection with C. neoformans in immunosuppressed patients show CP enlargement and enhancement (i.e. may indicate inflammation of the tissue) joined with cystic lesion within basal ganglia indicate also possible involvement of the CP in infection pathology (O’Connor et al. 2020).

\section{Parasites}

The CP has been a proven route of the CNS invasion for trypanosomes, a causative agent of sleeping disease/sickness (African trypanosomiasis) (Wolburg et al. 2012; Bentivoglio et al. 2018). Analysing electron micrographs of the brain, Falangola and Petito (1993) showed the presence of Toxoplasma gondii tachyzoites and pseudocysts in capillaries and stroma of the CP in the majority of AIDS patients deceased during acute necrotizing stages of cerebral toxoplasmosis, and in $20 \%$ of the patients with healed lesions, serving as a temporary hostile environment for parasites for further migration between layers of pia mater. High frequency of the $\mathrm{CP}$ infection with acute cerebral toxoplasmosis identified in the CP (in 53\% of all cases tested) was found in the patients with AIDS. Intracranial inoculation with Mesocestoides corti metacestodes resulted in parasites within the ventricular area, but infection seems not to alter the BCSFB, but ependyma, that authors suggest as the route of lymphocyte infiltration in the ventricular area in the course of infection (Alvarez and Teale 2007). 


\section{Connection of the CP to neurodevelopmental disorders and stress}

Neurodevelopmental disorders are a group of etiologically complex diseases, caused by genetic and environmental interactions interfering with proper early brain development, which later in life result in cognitive and behavioural impairments (van Loo and Martens 2007). Several groups have pointed at the presence of alterations in the CP physiology and in composition and flow of the CSF, in this group of conditions (Palha et al. 2012; Arasappa et al. 2013; Marinescu et al. 2013; Kim et al. 2016; Shen 2018; Lizano et al. 2019; Zhou et al. 2020). For example, genetic predisposition, combined with chronic low-grade inflammation caused by stress, perinatal inflammation during pregnancy and sleep disorders, seem to be 'fertile ground' for triggering changes in the CP implicated in onset and progression of autism and schizophrenia, samples of neurodevelopmental disorders (Demeestere et al. 2015). Kim et al. (2016) performed genome-wide expression profiling of the CPs from schizophrenic individuals and found upregulation of genes connected to immune response and inflammation, and their association to disease status, which indicates a potential protective effect of the CP in response to peripheral immune challenges. Neuroimaging pictures of schizophrenic patients show consistent mild lateral ventricular enlargement (Gilmore and Bouldin 2002). One of the consequences of disturbed brain $\mathrm{Ca}^{2+}$ homeostasis, probably originating from leakage of the $\mathrm{BBB}$, is calcification of the $\mathrm{CP}$, which seems can serve as a neuroimaging marker of poor-quality evaluation and cognitive impairment of schizophrenic patients (Marinescu et al. 2013). The CP in the perinatal stage responds to the immune status of the mother. The $\mathrm{CP}$ of the fetus responds to ongoing inflammation in the mother's body by an accumulation of immune cells within the tissue and intensified production of CCL2 and loosening of the barrier (Cui et al. 2020).

They found a connection between the size of the CP and chronic pain. Namely, the CP in the brain of patients suffering from complex regional pain syndrome (CRPS) showed a $21 \%$ volume increase in comparison to age- and gender-match controls, linking the $\mathrm{CP}$ with the pathology of the disease (Zhou et al. 2015). Further, the CP might help in 'coping' with stressful situations, as changes in its immunosurveillance seem to participate in stress resilience (Schwartz and Baruch 2012).

\section{Therapeutic potential lying in the $\mathrm{CP}$ tissue}

The CP shows neurogenic capabilities, and via the CSF secretion can stimulate such processes in distal tissues. The tissue itself contains a progenitor neural stem cell popula- tion capable of differentiation into various cells of the nervous system (Itokazu et al. 2006; Prasongchean et al. 2015). At the same time it also secretes neurotrophic factors (i.e. glial cell-derived neurotrophic factor, brain-derived neurotrophic factor, and nerve growth factor (Borlongan et al. 2004) that might influence neurogenesis within other CNS areas. These characteristics of the CP hold a very promising regenerative approach in the treatment of CNS injuries. For example, in a case of a stroke, immunohistochemical analysis showed the proliferation inside the CP (Li et al. 2002). Further, grafted syngeneic fragments of CP in the damaged spinal cord of rats resulted in robust regeneration of damaged axons with prolonged effect, while the CPECs grafted into pre-lesioned spinal cord showed differentiation potential towards astrocytes (Ide et al. 2001; Kitada et al. 2001). Transplants of the CPs into the brain of a mouse model of AD (i.e. APP/PS1 mice) showed a reduction of $\mathrm{A} \beta$ and p-tau, and memory improvement (Bolos et al. 2014).

Additionally, in close proximity to the $\mathrm{CP}$ of the lateral ventricle is the subventricular zone (SVZ), one of the brain areas with active neurogenesis in adulthood (Falcao et al. 2012). The CP acts as a niche of the SVZ, influencing stem cells activities and dynamics (i.e. proliferation and differentiation) via the release of secretome that can be modulated in accordance with the physiological state (Falcao et al. 2012; Silva-Vargas et al. 2016).

Usage of encapsulated CPECs cells (Thanos et al. 2010) and the CP implants in animal models showed to be a promising approach in the treatment of Alzheimer's disease, Huntington disease, cancer and stroke (Borlongan et al. 2007; Emerich and Borlongan 2009; Bolos et al. 2014). Encapsulated CPECs were also tested in human subjects suffering from Parkinson's disease, where their usage did not show improvement of the condition (Snow et al. 2019).

\section{Conclusion}

Functional CP-CSF interface is of vital importance for the proper functioning of the CNS, as its disturbances have been observed in numerous CNS pathologies. As a connector of the blood circulation and CSF, and an important part of the CNS' immunosurveillance, the CP can sense ongoing peripheral inflammation, provide an adequate immune response, and pass the signal further into other brain areas. At the same time, the studies indicated the presence of the mechanisms for self-protection within the tissue, as well as the ones for prevention of spreading of peripherally originated inflammation through the brain. Comprehensive changes in the CP morphology and functionality play an important part in the onset and progression of physiological aging and neurodegenerative conditions, 
such as $\mathrm{AD}$, marked by the presence of toxic protein burden in the brain and oxidative stress. Changes in the CP have been also observed in diseases of autoimmune nature, such as multiple sclerosis, where CP plays a crucial part in the infiltration of devastating immune cells into the CNS, accompanied by the immunological answer of the $\mathrm{CP}$ and junctional changes. Anatomical characteristics of the CP make it a 'favourite' route for invasion of many pathogens, even the one's origination from the gut, from where they can further infect the CNS, while some use it as a space for self-replication or reservoir. In the CNS, pathogens can induce profoundly serious conditions, such as encephalitis, meningitis and sepsis. Pathogen infection provokes distinct responses within the $\mathrm{CP}$ in terms of inflammation, and barrier disturbance. There are also indications about the $\mathrm{CP}$ as an entrance spot of SARS-CoV-2, connected with various neurological complications. Morphological changes in the $\mathrm{CP}$ may lead to changes in the CSF dynamics and ICP, as observed in the state of hydrocephalus, which is still being prevalently treated surgically. Tumors can also develop in the CP, mostly in childhood, and an anti-inflammatory treatment approach has been suggested. Disturbances in proper neurodevelopment impacting the CP morphology, and the CSF flow rate and composition, may be the onset of autism and schizophrenia. The CP changes have also been observed in chronic pain, and it is believed that the CP may be helpful in 'dealing' with the stress. Due to neuronal capacities within the tissue, and its support of neurogenic capacities of other CNS sites, it is not a surprise that the $\mathrm{CP}$ attracts a lot of attention in regenerative medicine. In this sense, the encapsulated CPECs and CP transplants have shown promising results in animal models of various diseases, while their implication in humans, still desired additional improvements.

In summary, there is much evidence and indications that the $\mathrm{CP}$ is an important part of pathological conditions within the CNS, and at the same time tissue that may 'hold the key' for a therapeutic approach to brain regeneration. Said this, future studies of physiological and pathological aspects of the CP, surely represent a significant step forward in the prevention and treatment of various CNS disorders.

Acknowledgements. This work was supported by grants APVV14-0547, APVV-18-0302, VEGA 2/0150/19 and VEGA 2/088/18. Authors would like to thank to Dr. Henrieta Dudekova for her help with preparation of graphics.

Conflict of interest. The authors declare that they have no competing interests.

Author contributions. SM was a major contributor to manuscript writing. $\mathrm{AM}, \mathrm{MB}$ and $\mathrm{AK}$ revised the manuscript critically for important intellectual content. All authors read and approved the final manuscript.

\section{References}

Alvarez JI, Teale JM (2007): Differential changes in junctional complex proteins suggest the ependymal lining as the main source of leukocyte infiltration into ventricles in murine neurocysticercosis. J. Neuroimmunol. 187, 102-113 https://doi.org/10.1016/j.jneuroim.2007.05.005

Alvarez JI, Cayrol R, Prat A (2011): Disruption of central nervous system barriers in multiple sclerosis. Biochim. Biophys. Acta 1812, 252-264

https://doi.org/10.1016/j.bbadis.2010.06.017

Alvira-Botero X, Carro EM (2010): Clearance of amyloid- $\beta$ peptide across the choroid plexus in Alzheimer's disease. Curr. Aging Sci. 3, 219-229

https://doi.org/10.2174/1874609811003030219

Annunziata P, Volpi N (1985): High levels of C3c in the cerebrospinal fluid from amyotrophic lateral sclerosis patients. Acta Neurol. Scand. 72, 61-64 https://doi.org/10.1111/j.1600-0404.1985.tb01548.x

Alzheimer's Association (2021): 2021 Alzheimer's disease facts and figures. Alzheimers Dement. 17, 327-406 https://doi.org/10.1002/alz.12328

Arasappa R, Danivas V, Venkatasubramanian G (2013): Choroid plexus papilloma presenting as schizophrenia: a case report. J. Neuropsychiatry Clin. Neurosci. 25, E26-E27

https://doi.org/10.1176/appi.neuropsych.12010017

Attier-Zmudka J, Sérot J-M, Valluy J, Saffarini M, Macaret A-S, Diouf M, Dao S, Douadi Y, Malinowski KP, Balédent O (2019): Decreased cerebrospinal fluid flow is associated with cognitive deficit in elderly patients. Front. Aging Neurosci. 11, 87 https://doi.org/10.3389/fnagi.2019.00087

Balusu S, Brkic M, Libert C, Vandenbroucke RE (2016): The choroid plexus-cerebrospinal fluid interface in Alzheimer's disease: more than just a barrier. Neural Regen. Res. 11, 534-537 https://doi.org/10.4103/1673-5374.180372

Banizs B, Pike MM, Millican CL, Ferguson WB, Komlosi P, Sheetz J, Bell PD, Schwiebert EM, Yoder BK (2005): Dysfunctional cilia lead to altered ependyma and choroid plexus function, and result in the formation of hydrocephalus. Development 132, 5329-5339 https://doi.org/10.1242/dev.02153

Baruch K, Deczkowska A, David E, Castellano JM, Miller O, Kertser A, Berkutzki T, Barnett-Itzhaki Z, Bezalel D, Wyss-Coray T, Amit I, Schwartz M (2014): Aging-induced type I interferon response at the choroid plexus negatively affects brain function. Science 346, 89 https://doi.org/10.1126/science.1252945

Baruch K, Kertser A, Porat Z, Schwartz M (2015): Cerebral nitric oxide represses choroid plexus NFkB-dependent gateway activity for leukocyte trafficking. EMBO J. 34, 1816-1828 https://doi.org/10.15252/embj.201591468

Bates CA, Fu S, Ysselstein D, Rochet JC, Zheng W (2015): Expression and transport of alpha-synuclein at the bloodcerebrospinal fluid barrier and effects of manganese exposure. ADMET 3, 15-33 https://doi.org/10.5599/admet.3.1.159

Bates CA, Zheng W (2014): Brain disposition of $\alpha$-synuclein: roles of brain barrier systems and implications for Parkinson's disease. Fluids Barriers CNS 11, 17 
https://doi.org/10.1186/2045-8118-11-17

Bentivoglio M, Kristensson K, Rottenberg ME (2018): Circumventricular organs and parasite neurotropism: Neglected gates to the brain? Front. Immunol. 9, 2877 https://doi.org/10.3389/fimmu.2018.02877

Bolos M, Antequera D, Aldudo J, Kristen H, Bullido MJ, Carro E (2014): Choroid plexus implants rescue Alzheimer's diseaselike pathologies by modulating amyloid- $\beta$ degradation. Cell. Mol. Life Sci. 71, 2947-2955 https://doi.org/10.1007/s00018-013-1529-4

Borkowski J, Li L, Steinmann U, Quednau N, Stump-Guthier C, Weiss C, Findeisen P, Gretz N, Ishikawa H, Tenenbaum T, et al. (2014): Neisseria meningitidiselicits a pro-inflammatory response involving $\mathrm{I} \kappa \mathrm{B} \zeta$ in a human blood-cerebrospinal fluid barrier model. J. Neuroinflammation 11, 163 https://doi.org/10.1186/s12974-014-0163-X

Borlongan CV, Skinner Steve JM, Geaney M, Vasconcellos Alfred V, Elliott Robert B, Emerich Dwaine F (2004): Intracerebral transplantation of porcine choroid plexus provides structural and functional neuroprotection in a rodent model of stroke. Stroke 35, 2206-2210 https://doi.org/10.1161/01.STR.0000138954.25825.0b

Borlongan CV, Thanos CG, Skinner SJM, Geaney M, Emerich DF (2007): Transplants of encapsulated rat choroid plexus cells exert neuroprotection in a rodent model of Huntington's disease. Cell Transplant. 16, 987-992 https://doi.org/10.3727/000000007783472426

Bothwell SW, Janigro D, Patabendige A (2019): Cerebrospinal fluid dynamics and intracranial pressure elevation in neurological diseases. Fluids Barriers CNS 16, 9 https://doi.org/10.1186/s12987-019-0129-6

Breuer J, Korpos E, Hannocks M-J, Schneider-Hohendorf T, Song J, Zondler L, Herich S, Flanagan K, Korn T, Zarbock A, et al. (2018): Blockade of MCAM/CD146 impedes CNS infiltration of T cells over the choroid plexus. J. Neuroinflammation 15, 236 https://doi.org/10.1186/s12974-018-1276-4

Bridi JC, Hirth F (2018): Mechanisms of $\alpha$-synuclein induced synaptopathy in parkinson's disease. Front. Neurosci. 12, 80 https://doi.org/10.3389/fnins.2018.00080

Brkic M, Balusu S, Libert C, Vandenbroucke RE (2015a): Friends or foes: matrix metalloproteinases and their multifaceted roles in neurodegenerative diseases. Mediators Inflamm. 2015, 620581 https://doi.org/10.1155/2015/620581

Brkic M, Balusu S, Van Wonterghem E, Gorlé N, Benilova I, Kremer A, Van Hove I, Moons L, De Strooper B, Kanazir S, et al. (2015b): Amyloid $\beta$ oligomers disrupt blood-CSF barrier integrity by activating matrix metalloproteinases. J. Neurosci. 35, 12766-12778 https://doi.org/10.1523/JNEUROSCI.0006-15.2015

Calhoun MC, Hurt HD, Eaton HD, Rousseau JE Jr., Hall RC Jr. (1967): Rates of formation and absorption of cerebrospinal fluid in bovine hypovitaminosis A. J. Dairy Sci. 50, 1489-1494 https://doi.org/10.3168/jds.S0022-0302(67)87653-7

Campos Y, Qiu X, Gomero E, Wakefield R, Horner L, Brutkowski W, Han Y-G, Solecki D, Frase S, Bongiovanni A, d'Azzo A (2016): Alix-mediated assembly of the actomyosin-tight junction polarity complex preserves epithelial polarity and epithelial barrier. Nat. Commun. 7, 11876 https://doi.org/10.1038/ncomms11876

Cardia E, Molina D, Abbate F, Mastroeni P, Stassi G, Germanà GP, Germanò A (1995): Morphological modifications of the choroid plexus in a rodent model of acute ventriculitis induced by gram-negative liquoral sepsis. Childs Nerv. Syst. 11, 511-516 https://doi.org/10.1007/BF00822840

Carrion E, Hertzog JH, Medlock MD, Hauser GJ, Dalton HJ (2001): Use of acetazolamide to decrease cerebrospinal fluid production in chronically ventilated patients with ventriculopleural shunts. Arch. Dis. Child. 84, 68 https://doi.org/10.1136/adc.84.1.68

Carro E, Spuch C, Trejo JL, Antequera D, Torres-Aleman I (2005): Choroid plexus megalin is involved in neuroprotection by serum insulin-like growth factor I. J. Neurosci. 25, 10884 https://doi.org/10.1523/JNEUROSCI.2909-05.2005

Castro Dias M, Coisne C, Lazarevic I, Baden P, Hata M, Iwamoto N, Francisco DMF, Vanlandewijck M, He L, Baier FA, et al. (2019): Claudin-3-deficient C57BL/6J mice display intact brain barriers. Sci. Rep. 9, 203 https://doi.org/10.1038/s41598-018-36731-3

Chalbot S, Zetterberg H, Blennow K, Fladby T, Andreasen N, Grundke-Iqbal I, Iqbal K (2011): Blood-cerebrospinal fluid barrier permeability in Alzheimer's disease. J. Alzheimers Dis. 25, 505-515 https://doi.org/10.3233/JAD-2011-101959

Chang YC, Stins MF, McCaffery MJ, Miller GF, Pare DR, Dam T, Paul-Satyasee M, Kim KS, Kwon-Chung KJ (2004): Cryptococcal yeast cells invade the central nervous system via transcellular penetration of the blood-brain barrier. Infect. Immun. 72, 4985 https://doi.org/10.1128/IAI.72.9.4985-4995.2004

Chen RL, Athauda SB, Kassem NA, Zhang Y, Segal MB, Preston JE (2005): Decrease of transthyretin synthesis at the bloodcerebrospinal fluid barrier of old sheep. J. Gerontol. A Biol. Sci. Med. Sci. 60, 852-858 https://doi.org/10.1093/gerona/60.7.852

Crossgrove JS, Li GJ, Zheng W (2005): The choroid plexus removes beta-amyloid from brain cerebrospinal fluid. Exp. Biol. Med. (Maywood) 230, 771-776 https://doi.org/10.1177/153537020523001011

Cserr HF, Harling-Berg CJ, Knopf PM (1992): Drainage of brain extracellular fluid into blood and deep cervical lymph and its immunological significance. Brain Pathol. 2, 269-276 https://doi.org/10.1111/j.1750-3639.1992.tb00703.x

Cui J, Shipley FB, Shannon ML, Alturkistani O, Dani N, Webb MD, Sugden AU, Andermann ML, Lehtinen MK (2020): Inflammation of the embryonic choroid plexus barrier following maternal immune activation. Dev. Cell 55, 617-628 https://doi.org/10.1016/j.devcel.2020.09.020

Damkier HH, Brown PD, Praetorius J (2013): cerebrospinal fluid secretion by the choroid plexus. Physiol. Rev. 93, 1847-1892 https://doi.org/10.1152/physrev.00004.2013

Dando SJ, Mackay-Sim A, Norton R, Currie BJ, St. John JA, Ekberg JAK, Batzloff M, Ulett GC, Beacham IR (2014): pathogens penetrating the central nervous system: infection pathways and the cellular and molecular mechanisms of invasion. Clin. Microbiol. Rev. 27, 691 https://doi.org/10.1128/CMR.00118-13 
Daum RS, Scheifele DW, Syriopoulou VP, Averill D, Smith AL (1978): Ventricular involvement in experimental Hemophilus influenzae meningitis. J. Pediatr. 93, 927-930 https://doi.org/10.1016/S0022-3476(78)81213-X

De Vadder F, Kovatcheva-Datchary P, Goncalves D, Vinera J, Zitoun C, Duchampt A, Bäckhed F, Mithieux G (2014): Microbiotagenerated metabolites promote metabolic benefits via gut-brain neural circuits. Cell 156, 84-96 https://doi.org/10.1016/j.cell.2013.12.016

Demeestere D, Libert C, Vandenbroucke RE (2015): Therapeutic implications of the choroid plexus-cerebrospinal fluid interface in neuropsychiatric disorders. Brain Behav. Immun. 50, 1-13 https://doi.org/10.1016/j.bbi.2015.06.010

Dickson K, Lehmann C (2019): Inflammatory response to different toxins in experimental sepsis models. Int. J. Mol. Sci. 20, 4341 https://doi.org/10.3390/ijms20184341

Dietrich MO, Spuch C, Antequera D, Rodal I, de Yébenes JG, Molina JA, Bermejo F, Carro E (2008): Megalin mediates the transport of leptin across the blood-CSF barrier. Neurobiol. Aging 29, 902-912 https://doi.org/10.1016/j.neurobiolaging.2007.01.008

Dixon GA, Pérez CA (2020): multiple sclerosis and the choroid plexus: emerging concepts of disease immunopathophysiology. Pediatr. Neurol. 103, 65-75 https://doi.org/10.1016/j.pediatrneurol.2019.08.007

Dohrmann GJ (1971): The choroid plexus in experimental hydrocephalus. A light and electron microscopic study in normal, hydrocephalic, and shunted hydrocephalic dogs. J. Neurosurg. 34, 56-69 https://doi.org/10.3171/jns.1971.34.1.0056

Domínguez-Punaro MC, Segura M, Plante M-M, Lacouture S, Rivest S, Gottschalk M (2007): Streptococcus suis serotype 2, an important swine and human pathogen, induces strong systemic and cerebral inflammatory responses in a mouse model of infection. J. Immunol. 179, 1842-1854 https://doi.org/10.4049/jimmunol.179.3.1842

Donnenfeld H, Kascsak RJ, Bartfeld H (1984): Deposits of IgG and $\mathrm{C} 3$ in the spinal cord and motor cortex of ALS patients. J. Neuroimmunol. 6, 51-57 https://doi.org/10.1016/0165-5728(84)90042-0

Dziegielewska KM, Evans CA, Malinowska DH, Møllgård K, Reynolds JM, Reynolds ML, Saunders NR (1979): Studies of the development of brain barrier systems to lipid insoluble molecules in fetal sheep. J. Physiol. 292, 207-231 https://doi.org/10.1113/jphysiol.1979.sp012847

Emerich DF, Borlongan CV (2009): Potential of choroid plexus epithelial cell grafts for neuroprotection in Huntington's disease: What remains before considering clinical trials. Neurotox. Res. 15, 205 https://doi.org/10.1007/s12640-009-9021-5

Emerich DF, Skinner SJM, Borlongan CV, Vasconcellos AV, Thanos CG (2005): The choroid plexus in the rise, fall and repair of the brain. Bioessays 27, 262-274 https://doi.org/10.1002/bies.20193

Engelhardt B, Wolburg-Buchholz K, Wolburg H (2001): Involvement of the choroid plexus in central nervous system inflammation. Microsc. Res. Tech. 52, 112-129
https://doi.org/10.1002/1097-0029(20010101)52:1<112::AID-JEMT13>3.0.CO;2-5

Engelhardt B, Ransohoff RM (2012): Capture, crawl, cross: the T cell code to breach the blood-brain barriers. Trends Immunol. 33, 579-589 https://doi.org/10.1016/j.it.2012.07.004

Eriksson L, Westermark P (1986): Intracellular neurofibrillary tangle-like aggregations. A constantly present amyloid alteration in the aging choroid plexus. Am. J. Pathol. 125, 124-129

Falangola MF, Petito CK (1993): Choroid plexus infection in cerebral toxoplasmosis in AIDS patients. Neurology 43, 2035-2040 https://doi.org/10.1212/WNL.43.10.2035

Falangola MF, Hanly A, Galvao-Castro B, Petito CK (1995): HIV infection of human choroid plexus: a possible mechanism of viral entry into the CNS. J. Neuropathol. Exp. Neurol. 54, 497-503 https://doi.org/10.1097/00005072-199507000-00003

Falcao A, Marques F, Novais A, Sousa N, Palha J, Sousa J (2012): The path from the choroid plexus to the subventricular zone: go with the flow! Front. Cell. Neurosci. 6, 34 https://doi.org/10.3389/fncel.2012.00034

Faraci FM, Mayhan WG, Heistad DD (1990): Effect of vasopressin on production of cerebrospinal fluid: possible role of vasopressin (V1)-receptors. Am. J. Physiol. 258, R94-R98 https://doi.org/10.1152/ajpregu.1990.258.1.R94

Faraci FM, Kinzenbaw D, Heistad DD (1994): Effect of endogenous vasopressin on blood flow to choroid plexus during hypoxia and intracranial hypertension. Am. J. Physiol. 266, H393-H398 https://doi.org/10.1152/ajpheart.1994.266.2.H393

Feuer R, Mena I, Pagarigan RR, Harkins S, Hassett DE, Whitton JL (2003): Coxsackievirus B3 and the neonatal CNS: the roles of stem cells, developing neurons, and apoptosis in infection, viral dissemination, and disease. Am. J. Pathol. 163, 1379-1393 https://doi.org/10.1016/S0002-9440(10)63496-7

Flannery CR (2006): MMPs and ADAMTSs: functional studies. Front. Biosci. 11, 544-569 https://doi.org/10.2741/1818

Foster JA (2013): Gut feelings: bacteria and the brain. Cerebrum 2013, 9

Fotuhi M, Mian A, Meysami S, Raji CA (2020): Neurobiology of COVID-19. J. Alzheimers Dis. 76, 3-19 https://doi.org/10.3233/JAD-200581

Frausto RF, Crocker SJ, Eam B, Whitmire JK, Whitton JL (2007): Myelin oligodendrocyte glycoprotein peptide-induced experimental allergic encephalomyelitis and $\mathrm{T}$ cell responses are unaffected by immunoproteasome deficiency. J. Neuroimmunol. 192, 124-133 https://doi.org/10.1016/j.jneuroim.2007.09.024

Garbuzova-Davis S, Sanberg P (2014): Blood-CNS barrier impairment in ALS patients versus an animal model. Front. Cell. Neurosci. 8, 21 https://doi.org/10.3389/fncel.2014.00021

Gelb S, Stock AD, Anzi S, Putterman C, Ben-Zvi A (2018): Mechanisms of neuropsychiatric lupus: The relative roles of the blood-cerebrospinal fluid barrier versus blood-brain barrier. J. Autoimmun. 91, 34-44 https://doi.org/10.1016/j.jaut.2018.03.001 
Ghersi-Egea J-F, Strazielle N (2001): Brain drug delivery, drug metabolism, and multidrug resistance at the choroid plexus. Microsc. Res. Tech. 52, 83-88

https://doi.org/10.1002/1097-0029(20010101)52:1<83::AID-JEMT10>3.0.CO;2-N

Ghersi-Egea J-F, Strazielle N, Catala M, Silva-Vargas V, Doetsch F, Engelhardt B (2018): Molecular anatomy and functions of the choroidal blood-cerebrospinal fluid barrier in health and disease. Acta Neuropathol. 135, 337-361 https://doi.org/10.1007/s00401-018-1807-1

Gilmore JH, Bouldin TW (2002): Analysis of ependymal abnormalities in subjects with schizophrenia, bipolar disorder, and depression. Schizophr. Res. 57, 267-271 https://doi.org/10.1016/S0920-9964(01)00294-8

Go KG, Stokroos I, Blaauw EH, Zuiderveen F, Molenaar I (1976): Changes of ventricular ependyma and choroid plexus in experimental hydrocephalus, as observed by scanning electron microscopy. Acta Neuropathol. 34, 55-64 https://doi.org/10.1007/BF00684944

González-Marrero I, Giménez-Llort L, Johanson CE, CarmonaCalero EM, Castañeyra-Ruiz L, Brito-Armas JM, CastañeyraPerdomo A, Castro-Fuentes R (2015): Choroid plexus dysfunction impairs beta-amyloid clearance in a triple transgenic mouse model of Alzheimer's disease. Front. Cell. Neurosci. 9, 17 https://doi.org/10.3389/fncel.2015.00017

Gorlé N, Blaecher C, Bauwens E, Vandendriessche C, Balusu S, Vandewalle J, Van Cauwenberghe C, Van Wonterghem E, Van Imschoot G, Liu C, et al. (2018): The choroid plexus epithelium as a novel player in the stomach-brain axis during Helicobacter infection. Brain Behav. Immun. 69, 35-47 https://doi.org/10.1016/j.bbi.2017.12.010

Grote E, Hassler W (1988): The critical first minutes after subarachnoid hemorrhage. Neurosurgery 22, 654-661 https://doi.org/10.1227/00006123-198804000-00006

Gründler T, Quednau N, Stump C, Orian-Rousseau V, Ishikawa H, Wolburg H, Schroten H, Tenenbaum T, Schwerk C (2013): The surface proteins InlA and InlB are interdependently required for polar basolateral invasion by Listeria monocytogenes in a human model of the blood-cerebrospinal fluid barrier. Microb. Infect. 15, 291-301 https://doi.org/10.1016/j.micinf.2012.12.005

Hampel H, Kötter HU, Möller HJ (1997): Blood-cerebrospinal fluid barrier dysfunction for high molecular weight proteins in Alzheimer disease and major depression: indication for disease subsets. Alzheimer Dis. Assoc. Disord. 11, 78-87 https://doi.org/10.1097/00002093-199706000-00004

Han S, Lin YC, Wu T, Salgado AD, Mexhitaj I, Wuest SC, Romm E, Ohayon J, Goldbach-Mansky R, Vanderver A, et al. (2014): Comprehensive immunophenotyping of cerebrospinal fluid cells in patients with neuroimmunological diseases. J. Immunol. 192, 2551-2563 https://doi.org/10.4049/jimmunol.1302884

Hardy J, Selkoe DJ (2002): The amyloid hypothesis of Alzheimers disease: Progress and problems on the road to therapeutics. Science 297, 353-356 https://doi.org/10.1126/science.1072994

Hasselblatt M, Mertsch S, Koos B, Riesmeier B, Stegemann H, Jeibmann A, Tomm M, Schmitz N, Wrede B, Wolff JE, et al.
(2009): TWIST-1 is overexpressed in neoplastic choroid plexus epithelial cells and promotes proliferation and invasion. Cancer Res. 69, 2219-2523

https://doi.org/10.1158/0008-5472.CAN-08-3176

Hladky SB, Barrand MA (2014): Mechanisms of fluid movement into, through and out of the brain: evaluation of the evidence. Fluids Barriers CNS 11, 26

https://doi.org/10.1186/2045-8118-11-26

Hsiao EY, McBride SW, Hsien S, Sharon G, Hyde ER, McCue T, Codelli JA, Chow J, Reisman SE, Petrosino JF, et al. (2013): Microbiota modulate behavioral and physiological abnormalities associated with neurodevelopmental disorders. Cell 155, 1451-1463 https://doi.org/10.1016/j.cell.2013.11.024

Huang H-I, Shih S-R (2015): Neurotropic enterovirus infections in the central nervous system. Viruses 7, 6051-6066 https://doi.org/10.3390/v7112920

Huang S-H, Wu C-H, Chang YC, Kwon-Chung KJ, Brown RJ, Jong A (2012): Cryptococcus neoformans-derived microvesicles enhance the pathogenesis of fungal brain infection. PLoS One 7, e48570 https://doi.org/10.1371/journal.pone.0048570

Ide C, Kitada M, Chakrabortty S, Taketomi M, Matsumoto N, Kikukawa S, Mizoguchi A, Kawaguchi S, Endoh K, Suzuki Y (2001): Grafting of choroid plexus ependymal cells promotes the growth of regenerating axons in the dorsal funiculus of rat spinal cord: a preliminary report. Exp. Neurol. 167, 242-251 https://doi.org/10.1006/exnr.2000.7566

Iliff JJ, Wang M, Liao Y, Plogg BA, Peng W, Gundersen GA, Benveniste $H$, Vates GE, Deane R, Goldman SA, et al. (2012): A paravascular pathway facilitates CSF flow through the brain parenchyma and the clearance of interstitial solutes, including amyloid $\beta$. Sci. Transl. Med. 4, 147ra111 https://doi.org/10.1126/scitranslmed.3003748

Itokazu Y, Kitada M, Dezawa M, Mizoguchi A, Matsumoto N, Shimizu A, Ide C (2006): Choroid plexus ependymal cells host neural progenitor cells in the rat. Glia 53, 32-42 https://doi.org/10.1002/glia.20255

Ivkovic M, Reiss-Zimmermann M, Katzen H, Preuss M, Kovanlikaya I, Heier L, Alperin N, Hoffmann KT, Relkin N (2015): MRI assessment of the effects of acetazolamide and external lumbar drainage in idiopathic normal pressure hydrocephalus. Fluids Barriers CNS 12, 9

https://doi.org/10.1186/s12987-015-0004-Z

Jadhav S, Avila J, Schöll M, Kovacs GG, Kövari E, Skrabana R, Evans LD, Kontsekova E, Malawska B, de Silva R, et al. (2019): A walk through tau therapeutic strategies. Acta Neuropathol. Commun. 7, 22 https://doi.org/10.1186/s40478-019-0664-Z

Johanson C (2018): Choroid plexus blood-CSF barrier: major player in brain disease modeling and neuromedicine. J. Neurol. Neuromed. 3, 39-58

https://doi.org/10.29245/2572.942X/2018/4.1194

Johanson C, McMillan P, Tavares R, Spangenberger A, Duncan J, Silverberg G, Stopa E (2004): Homeostatic capabilities of the choroid plexus epithelium in Alzheimer's disease. Cerebrospinal Fluid Res. 1, 3 https://doi.org/10.1186/1743-8454-1-3 
Jong A, Wu C-H, Shackleford GM, Kwon-Chung KJ, Chang YC, Chen H-M, Ouyang Y, Huang S-H (2008): Involvement of human CD44 during Cryptococcus neoformans infection of brain microvascular endothelial cells. Cell. Microbiol. 10, 1313-1326 https://doi.org/10.1111/j.1462-5822.2008.01128.x

Jovanović I, Ugrenović S, Vasović L, Petrović D, Cekić S (2010): Psammoma bodies - friends or foes of the aging choroid plexus. Med. Hypotheses 74, 1017-1020 https://doi.org/10.1016/j.mehy.2010.01.006

Kahle KT, Kulkarni AV, Limbrick DD, Jr., Warf BC (2016): Hydrocephalus in children. Lancet 387, 788-799 https://doi.org/10.1016/S0140-6736(15)60694-8

Kant S, Stopa EG, Johanson CE, Baird A, Silverberg GD (2018): Choroid plexus genes for CSF production and brain homeostasis are altered in Alzheimer's disease. Fluids Barriers CNS 15, 34 https://doi.org/10.1186/s12987-018-0120-7

Karimy JK, Duran D, Hu JK, Gavankar C, Gaillard JR, Bayri Y, Rice H, Diluna ML, Gerzanich V, Marc Simard J, Kahle KT (2016): Cerebrospinal fluid hypersecretion in pediatric hydrocephalus. Neurosurg. Focus 41, E10 https://doi.org/10.3171/2016.8.FOCUS16278

Kaur C, Rathnasamy G, Ling E-A (2016): The choroid plexus in healthy and diseased brain. J. Neuropathol. Exp. Neurol. 75, 198-213 https://doi.org/10.1093/jnen/nlv030

Kaur G, Trowsdale J, Fugger L (2013): Natural killer cells and their receptors in multiple sclerosis. Brain 136, 2657-2676 https://doi.org/10.1093/brain/aws159

Kelly JR, Minuto C, Cryan JF, Clarke G, Dinan TG (2017): Cross talk: the microbiota and neurodevelopmental disorders. Front. Neurosci. 11, 490 https://doi.org/10.3389/fnins.2017.00490

Kent SA, Spires-Jones TL, Durrant CS (2020): The physiological roles of tau and $A \beta$ : implications for Alzheimer's disease pathology and therapeutics. Acta Neuropathol. 140, 417-447 https://doi.org/10.1007/s00401-020-02196-w

Kiktenko AI (1986): Biondi bodies in the choroid plexus epithelium of the human brain. Cell Tissue Res. 244, 239-240 https://doi.org/10.1007/BF00218405

Kim KS (2010): Acute bacterial meningitis in infants and children. Lancet Infect. Dis. 10, 32-42 https://doi.org/10.1016/S1473-3099(09)70306-8

Kim S, Hwang Y, Lee D, Webster MJ (2016): Transcriptome sequencing of the choroid plexus in schizophrenia. Transl. Psychiatry 6, e964 https://doi.org/10.1038/tp.2016.229

Kinney JW, Bemiller SM, Murtishaw AS, Leisgang AM, Salazar AM, Lamb BT (2018): Inflammation as a central mechanism in Alzheimer's disease. Alzheimers Dement. (NY) 4, 575-590 https://doi.org/10.1016/j.trci.2018.06.014

Kirchner A, Koedel U, Fingerle V, Paul R, Wilske B, Pfister HW (2000): Upregulation of matrix metalloproteinase-9 in the cerebrospinal fluid of patients with acute Lyme neuroborreliosis. J. Neurol. Neurosurg. Psychiatry 68, 368-371 https://doi.org/10.1136/jnnp.68.3.368

Kitada M, Chakrabortty S, Matsumoto N, Taketomi M, Ide C (2001): Differentiation of choroid plexus ependymal cells into astrocytes after grafting into the pre-lesioned spinal cord in mice. Glia 36, 364-374

https://doi.org/10.1002/glia.1123

Knuckey NW, Preston J, Palm D, Epstein MH, Johanson C (1993): Hydrocephalus decreases chloride efflux from the choroid plexus epithelium. Brain Res. 618, 313-317 https://doi.org/10.1016/0006-8993(93)91282-W

Kooij G, Kroon J, Paul D, Reijerkerk A, Geerts D, van der Pol SMA, van het Hof B, Drexhage JA, van Vliet SJ, Hekking LHP, et al. (2014): P-glycoprotein regulates trafficking of CD8+ T cells to the brain parenchyma. Acta Neuropathol. 127, 699-711 https://doi.org/10.1007/s00401-014-1244-8

Korn T, Bettelli E, Oukka M, Kuchroo VK (2009): IL-17 and Th17 cells. Annu. Rev. Immunol. 27, 485-517 https://doi.org/10.1146/annurev.immunol.021908.132710

Korting C, van Zwieten EJ, Boer GJ, Ravid R, Swaab DF (1996): Increase in vasopressin binding sites in the human choroid plexus in Alzheimer's disease. Brain Res. 706, 151-154 https://doi.org/10.1016/0006-8993(95)01242-7

Krishnamurthy S, Li J (2014): New concepts in the pathogenesis of hydrocephalus. Transl. Pediatr. 3, 185-194

Krzyzanowska A, Carro E (2012): Pathological alteration in the choroid plexus of Alzheimer's disease: Implication for new therapy approaches. Front. Pharmacol. 3, 75 https://doi.org/10.3389/fphar.2012.00075

Kumari R, Raval M, Dhun A (2010): Cryptococcal choroid plexitis: rare imaging findings of central nervous system cryptococcal infection in an immunocompetent individual. Br. J. Radiol. 83, e14-17 https://doi.org/10.1259/bjr/50945216

Kunis G, Baruch K, Miller O, Schwartz M (2015): Immunization with a myelin-derived antigen activates the brain's choroid plexus for recruitment of immunoregulatory cells to the CNS and attenuates disease progression in a mouse model of ALS. J. Neurosci. 35, 6381-6393 https://doi.org/10.1523/JNEUROSCI.3644-14.2015

Kuwabara T, Ishikawa F, Kondo M, Kakiuchi T (2017): The role of IL-17 and related cytokines in inflammatory autoimmune diseases. Mediators Inflamm. 2017, 3908061 https://doi.org/10.1155/2017/3908061

Lauer AN, Tenenbaum T, Schroten H, Schwerk C (2017): The diverse cellular responses of the choroid plexus during infection of the central nervous system. Am. J. Physiol. 314, C152-C165 https://doi.org/10.1152/ajpcell.00137.2017

Lehtinen MK, Bjornsson CS, Dymecki SM, Gilbertson RJ, Holtzman DM, Monuki ES (2013): The choroid plexus and cerebrospinal fluid: emerging roles in development, disease, and therapy. J. Neurosci. 33, 17553-17559

https://doi.org/10.1523/JNEUROSCI.3258-13.2013

Leonardi A, Abbruzzese G, Arata L, Cocito L, Vische M (1984): Cerebrospinal fluid (CSF) findings in amyotrophic lateral sclerosis. J. Neurol. 231, 75-78 https://doi.org/10.1007/BF00313720

Li Y, Chen J, Chopp M (2002): Cell proliferation and differentiation from ependymal, subependymal and choroid plexus cells in response to stroke in rats. J. Neurol. Sci. 193, 137-146 https://doi.org/10.1016/S0022-510X(01)00657-8 
Liddelow SA, Dziegielewska KM, VandeBerg JL, Saunders NR (2010): Development of the lateral ventricular choroid plexus in a marsupial, Monodelphis domestica. Cerebrospinal Fluid Res. 7, 16 https://doi.org/10.1186/1743-8454-7-16

Liddelow SA (2015): Development of the choroid plexus and bloodCSF barrier. Front. Neurosci. 9, 32 https://doi.org/10.3389/fnins.2015.00032

Lin H, Leng X, Qin C-h, Du Y-x, Wang W-s, Qiu S-j (2019): Choroid plexus tumours on MRI: similarities and distinctions in different grades. Cancer Imaging 19, 17 https://doi.org/10.1186/s40644-019-0200-1

Liptak GS (2007): Mosby's Pediatric Clinical Advisor. Elsevier

Liu B, Chen S, Johnson C, Helms JA (2014): A ciliopathy with hydrocephalus, isolated craniosynostosis, hypertelorism, and clefting caused by deletion of Kif3a. Reprod. Toxicol. 48, 88-97 https://doi.org/10.1016/j.reprotox.2014.05.009

Lizano P, Lutz O, Ling G, Lee AM, eum s, bishop jr, kelly s, pasternak o, clementz b, pearlson g, et al. (2019): association of choroid plexus enlargement with cognitive, inflammatory, and structural phenotypes across the psychosis spectrum. Am. J. Psychiatry 176, 564-572 https://doi.org/10.1176/appi.ajp.2019.18070825

Logsdon AF, Erickson MA, Rhea EM, Salameh TS, Banks WA (2018): Gut reactions: How the blood-brain barrier connects the microbiome and the brain. Exp. Biol. Med. (Maywood) 243, 159-165 https://doi.org/10.1177/1535370217743766

Longatti P, Basaldella L, Orvieto E, Dei Tos A, Martinuzzi A (2006): Aquaporin(s) expression in choroid plexus tumours. Pediatr. Neurosurg. 42, 228-233 https://doi.org/10.1159/000092359

Lorenzo AV, Page LK, Watters GV (1970): Relationship between cerebrospinal fluid formation, absorption and pressure in human hydrocephalus. Brain 93, 679-692 https://doi.org/10.1093/brain/93.4.679

Lu J, Kaur C, Ling EA (1996): An immunohistochemical study of the intraventricular macrophages in induced hydrocephalus in prenatal rats following a maternal injection of 6-aminonicotinamide. J. Anat. 188, 491-495

Lucht F, Cordier G, Pozzetto B, Frésard A, Revillard J-P (1992): Evidence for T-cell involvement during the acute phase of echo virus meningitis. J. Med. Virol. 38, 92-96 https://doi.org/10.1002/jmv.1890380204

Lun MP, Monuki ES, Lehtinen MK (2015): Development and functions of the choroid plexus-cerebrospinal fluid system. Nat. Rev. Neurosci. 16, 445-457 https://doi.org/10.1038/nrn3921

Madhavi C, Jacob M (1995): Light \& electron microscopic structure of choroid plexus in hydrocephalic guinea pig. Indian J. Med. Res. 101, 217-224

Madsen LW, Svensmark B, Elvestad K, Aalbaek B, Jensen HE (2002): Streptococcus suis serotype 2 infection in pigs: new diagnostic and pathogenetic aspects. J. Comp. Pathol. 126, 57-65 https://doi.org/10.1053/jcpa.2001.0522

Mao L, Wang M, Chen S, He Q, Chang J, Hong C, Zhou Y, Wang D, Li Y, Jin H, Hu B (2020): Neurological manifestations of hospitalized patients with COVID-19 in Wuhan, China: a retrospective case series study. (In press) https://doi.org/10.2139/ssrn.3544840

Marinescu I, Udriştoiu I, Marinescu D (2013): Choroid plexus calcification: clinical, neuroimaging and histopathological correlations in schizophrenia. Rom. J. Morphol. Embryol. 54, 365-369

Marques F, Sousa JC, Coppola G, Falcao AM, Rodrigues AJ, Geschwind DH, Sousa N, Correia-Neves M, Palha JA (2009): Kinetic profile of the transcriptome changes induced in the choroid plexus by peripheral inflammation. J. Cereb. Blood Flow Metab. 29, 921-932 https://doi.org/10.1038/jcbfm.2009.15

Marques F, Mesquita S, Sousa J, Coppola G, Gao F, Geschwind D, Columba-cabezas S, Aloisi F, Degna M, Cerqueira J, et al. (2012): Lipocalin 2 is present in the EAE brain and is modulated by natalizumab. Front. Cell. Neurosci. 6, 33 https://doi.org/10.3389/fncel.2012.00033

Martin R, Sospedra M, Rosito M, Engelhardt B (2016): Current multiple sclerosis treatments have improved our understanding of MS autoimmune pathogenesis. Eur. J. Immunol. 46, 2078-2090 https://doi.org/10.1002/eji.201646485

Mawuenyega KG, Sigurdson W, Ovod V, Munsell L, Kasten T, Morris JC, Yarasheski KE, Bateman RJ (2010): Decreased clearance of CNS beta-amyloid in Alzheimer's disease. Science 330, 1774 https://doi.org/10.1126/science.1197623

McComb RD, Burger PC (1983): Choroid plexus carcinoma: Report of a case with lmmunohistochemical and ultrastructural observations. Cancer 51, 470-475

https://doi.org/10.1002/1097-0142(19830201)51:3<470::AID-CNCR2820510319>3.0.CO;2-K

Merve A, Zhang X, Pomella N, Acquati S, Hoeck JD, Dumas A, Rosser G, Li Y, Jeyapalan J, Vicenzi S, et al. (2019): c-MYC overexpression induces choroid plexus papillomas through a T-cell mediated inflammatory mechanism. Acta Neuropathol. Commun. 7, 95 https://doi.org/10.1186/s40478-019-0739-x

Mesquita SD, Ferreira AC, Gao F, Coppola G, Geschwind DH, Sousa JC, Correia-Neves M, Sousa N, Palha JA, Marques F (2015): The choroid plexus transcriptome reveals changes in type I and II interferon responses in a mouse model of Alzheimer's disease. Brain Behav. Immun. 49, 280-292 https://doi.org/10.1016/j.bbi.2015.06.008

Møllgård K, Jacobsen M, Jacobsen GK, Clausen PP, Saunders NR (1979): Immunohistochemical evidence for an intracellular localization of plasma proteins in human foetal choroid plexus and brain. Neurosci. Lett. 14, 85-90 https://doi.org/10.1016/0304-3940(79)95349-7

Montalvan V, Lee J, Bueso T, De Toledo J, Rivas K (2020): Neurological manifestations of COVID-19 and other coronavirus infections: A systematic review. Clin. Neurol. Neurosurg. 194, 105921

https://doi.org/10.1016/j.clineuro.2020.105921

Moriguchi T, Harii N, Goto J, Harada D, Sugawara H, Takamino J, Ueno M, Sakata H, Kondo K, Myose N, et al. (2020): A first case of meningitis/encephalitis associated with SARS-Coronavirus-2. Int. J. Infect. Dis. 94, 55-58 https://doi.org/10.1016/j.ijid.2020.03.062 
Mormino EC, Papp KV (2018): Amyloid accumulation and cognitive decline in clinically normal older individuals: implications for aging and early Alzheimer's disease. J. Alzheimers Dis. 64, 633-646 https://doi.org/10.3233/JAD-179928

Murugesan N, Paul D, Lemire Y, Shrestha B, Ge S, Pachter JS (2012): Active induction of experimental autoimmune encephalomyelitis by MOG35-55 peptide immunization is associated with differential responses in separate compartments of the choroid plexus. Fluids Barriers CNS 9, 15 https://doi.org/10.1186/2045-8118-9-15

Narita K, Takeda S (2015): Cilia in the choroid plexus: their roles in hydrocephalus and beyond. Front. Cell. Neurosci. 9, 39 https://doi.org/10.3389/fncel.2015.00039

Nelson PT, Braak H, Markesbery WR (2009): Neuropathology and cognitive impairment in Alzheimer disease: a complex but coherent relationship. J. Neuropathol. Exp. Neurol. 68, 1-14 https://doi.org/10.1097/NEN.0b013e3181919a48

Nilsson C, Stahlberg F, Gideon P, Thomsen C, Henriksen O (1994): The nocturnal increase in human cerebrospinal fluid production is inhibited by a beta 1-receptor antagonist. Am. J. Physiol. 267, R1445-R1448 https://doi.org/10.1152/ajpregu.1994.267.6.R1445

Norkett W, McLone DG, Bowman R (2016): Current management strategies of hydrocephalus in the child with open spina bifida. Top Spinal Cord Inj. Rehabil. 22, 241-246 https://doi.org/10.1310/sci2204-241

O‘Connor KP, Pelargos PE, Milton CK, Peterson JEG, Bohnstedt B (2020): Cryptococcal choroid plexitis and non-communicating hydrocephalus. Cureus 12, e8512 https://doi.org/10.7759/cureus.8512

Oi S (2011): Classification of hydrocephalus: critical analysis of classification categories and advantages of „Multi-categorical Hydrocephalus Classification“ (Mc HC). Childs Nerv. Syst. 27, 1523 https://doi.org/10.1007/s00381-011-1542-6

Ott BR, Cohen RA, Gongvatana A, Okonkwo OC, Johanson CE, Stopa EG, Donahue JE, Silverberg GD, Alzheimer's Disease Neuroimaging I (2010): Brain ventricular volume and cerebrospinal fluid biomarkers of Alzheimer's disease. J. Alzheimers Dis. 20, 647-657 https://doi.org/10.3233/JAD-2010-1406

Ott BR, Jones RN, Daiello LA, de la Monte SM, Stopa EG, Johanson CE, Denby C, Grammas P (2018): Blood-cerebrospinal fluid barrier gradients in mild cognitive impairment and Alzheimer's disease: relationship to inflammatory cytokines and chemokines. Front. Aging Neurosci. 10, 245 https://doi.org/10.3389/fnagi.2018.00245

Owler BK, Pitham T, Wang D (2010): Aquaporins: relevance to cerebrospinal fluid physiology and therapeutic potential in hydrocephalus. Cerebrospinal Fluid Res. 7, 15 https://doi.org/10.1186/1743-8454-7-15

Palha J, Santos N, Marques F, Sousa J, Bessa J, Miguelote R, Sousa N, Belmonte de Abreu P (2012): Do genes and environment meet to regulate cerebrospinal fluid dynamics? Relevance for schizophrenia. Front. Cell. Neurosci. 6, 31 https://doi.org/10.3389/fncel.2012.00031

Pardridge WM (2016): CSF, blood-brain barrier, and brain drug delivery. Expert Opin Drug Deliv. 13, 963-975 https://doi.org/10.1517/17425247.2016.1171315

Pascale CL, Miller MC, Chiu C, Boylan M, Caralopoulos IN, Gonzalez L, Johanson CE, Silverberg GD (2011): Amyloidbeta transporter expression at the blood-CSF barrier is agedependent. Fluids Barriers CNS 8, 21 https://doi.org/10.1186/2045-8118-8-21

Pellegrini L, Albecka A, Mallery DL, Kellner MJ, Paul D, Carter AP, James LC, Lancaster MA (2020): SARS-CoV-2 infects the brain choroid plexus and disrupts the blood-CSF barrier in human brain organoids. Cell Stem Cell. 27, 951-961 https://doi.org/10.1016/j.stem.2020.10.001

Petito CK, Chen H, Mastri AR, Torres-Munoz J, Roberts B, Wood C (1999): HIV infection of choroid plexus in AIDS and asymptomatic HIV-infected patients suggests that the choroid plexus may be a reservoir of productive infection. J. Neurovirol. 5, 670-677 https://doi.org/10.3109/13550289909021295

Pisani V, Stefani A, Pierantozzi M, Natoli S, Stanzione P, Franciotta D, Pisani A (2012): Increased blood-cerebrospinal fluid transfer of albumin in advanced Parkinson's disease. J. Neuroinflammation 9,188 https://doi.org/10.1186/1742-2094-9-188

Prasongchean W, Vernay B, Asgarian Z, Jannatul N, Ferretti P (2015): The neural milieu of the developing choroid plexus: neural stem cells, neurons and innervation. Front. Neurosci. 9, 103 https://doi.org/10.3389/fnins.2015.00103

Prats N, Briones V, Blanco MM, Altimira J, Ramos JA, Domínguez L, Marco A (1992): Choroiditis and meningitis in experimental murine infection withListeria monocytogenes. Eur. J. Clin. Microbiol. Infect. Dis. 11, 744-747

https://doi.org/10.1007/BF01989983

Preston JE (2001): Ageing choroid plexus-cerebrospinal fluid system. Microsc. Res. Tech. 52, 31-37

https://doi.org/10.1002/1097-0029(20010101)52:1<31::AID-JEMT5 $>3.0 . C O ; 2-\mathrm{T}$

Puccini JM, Ruller CM, Robinson SM, Knopp KA, Buchmeier MJ, Doran KS, Feuer R (2014): Distinct neural stem cell tropism, early immune activation, and choroid plexus pathology following coxsackievirus infection in the neonatal central nervous system. Lab. Invest. 94, 161-181 https://doi.org/10.1038/labinvest.2013.138

Raha-Chowdhury R, Henderson JW, Raha AA, Vuono R, Bickerton A, Jones E, Fincham R, Allinson K, Holland A, Zaman SH (2019): Choroid plexus acts as gatekeeper for TREM2, abnormal accumulation of ApoE, and fibrillary tau in Alzheimer's disease and in down syndrome dementia. J. Alzheimers Dis. 69, 91-109 https://doi.org/10.3233/JAD-181179

Rangachari M, Kuchroo VK (2013): Using EAE to better understand principles of immune function and autoimmune pathology. J. Autoimmun. 45, 31-39 https://doi.org/10.1016/j.jaut.2013.06.008

Ransohoff RM (2007): Natalizumab for multiple sclerosis. N. Engl. J. Med. 356, 2622-2629 https://doi.org/10.1056/NEJMct071462

Ravits J (2014): Focality, stochasticity and neuroanatomic propagation in ALS pathogenesis. Exp. Neurol. 262, 121-126 https://doi.org/10.1016/j.expneurol.2014.07.021 
Reboldi A, Coisne C, Baumjohann D, Benvenuto F, Bottinelli D, Lira S, Uccelli A, Lanzavecchia A, Engelhardt B, Sallusto F (2009): C-C chemokine receptor 6-regulated entry of TH-17 cells into the CNS through the choroid plexus is required for the initiation of EAE. Nat. Immunol. 10, 514-523 https://doi.org/10.1038/ni.1716

Redzic Z (2011): Molecular biology of the blood-brain and the blood-cerebrospinal fluid barriers: similarities and differences. Fluids Barriers CNS 8, 3 https://doi.org/10.1186/2045-8118-8-3

Redzic ZB, Preston JE, Duncan JA, Chodobski A, SzmydyngerChodobska J (2005): The choroid plexus-cerebrospinal fluid system: from development to aging. In: Current Topics in Developmental Biology, pp 1-52, Academic Press https://doi.org/10.1016/S0070-2153(05)71001-2

Redzic ZB, Segal MB (2004): The structure of the choroid plexus and the physiology of the choroid plexus epithelium. Adv. Drug Del. Rev. 56, 1695-1716 https://doi.org/10.1016/j.addr.2004.07.005

Reiber H (1994): Flow rate of cerebrospinal fluid (CSF) - a concept common to normal blood-CSF barrier function and to dysfunction in neurological diseases. J. Neurol. Sci. 122, 189-203 https://doi.org/10.1016/0022-510X(94)90298-4

Reiber H (1995): External quality assessment in clinical neurochemistry: survey of analysis for cerebrospinal fluid (CSF) proteins based on CSF/serum quotients. Clin. Chem. 41, 256-263 https://doi.org/10.1093/clinchem/41.2.256

Reich DS, Lucchinetti CF, Calabresi PA (2018): Multiple sclerosis. N. Engl. J. Med. 378, 169-180 https://doi.org/10.1056/NEJMra1401483

Rickert CH, Paulus W (2001): Tumors of the choroid plexus. Microsc. Res. Tech. 52, 104-111 https://doi.org/10.1002/1097-0029(20010101)52:1<104::AID-JEMT12>3.0.CO;2-3

Rodrigue KM, Kennedy KM, Devous MD, Sr., Rieck JR, Hebrank AC, Diaz-Arrastia R, Mathews D, Park DC (2012): $\beta$-Amyloid burden in healthy aging: regional distribution and cognitive consequences. Neurology 78, 387-395 https://doi.org/10.1212/WNL.0b013e318245d295

Rodríguez-Lorenzo S, Konings J, van der Pol S, Kamermans A, Amor S, van Horssen J, Witte ME, Kooij G, de Vries HE (2020): Inflammation of the choroid plexus in progressive multiple sclerosis: accumulation of granulocytes and T cells. Acta Neuropathol. Commun. 8, 9 https://doi.org/10.1186/s40478-020-00899-5

Rose R, Häuser S, Stump-Guthier C, Weiss C, Rohde M, Kim KS, Ishikawa H, Schroten H, Schwerk C, Adam R (2018): Virulence factor-dependent basolateral invasion of choroid plexus epithelial cells by pathogenic Escherichia coli in vitro. FEMS Microbiol. Lett. 365 https://doi.org/10.1093/femsle/fny274

Sakka L, Coll G, Chazal J (2011): Anatomy and physiology of cerebrospinal fluid. Eur. Ann. Otorhinolaryngol. Head Neck Dis. 128, 309-316 https://doi.org/10.1016/j.anorl.2011.03.002

Saul J, Hutchins E, Reiman R, Saul M, Ostrow LW, Harris BT, Van Keuren-Jensen K, Bowser R, Bakkar N (2020): Global altera- tions to the choroid plexus blood-CSF barrier in amyotrophic lateral sclerosis. Acta Neuropathol. Commun. 8, 92 https://doi.org/10.1186/s40478-020-00968-9

Saul J, Hutchins E, Reiman R, Saul M, Ostrow LW, Harris BT, Van Keuren-Jensen K, Bowser R, Bakkar N (2020): Global alterations to the choroid plexus blood-CSF barrier in amyotrophic lateral sclerosis. Acta Neuropathol. Commun. 8, 92 https://doi.org/10.1186/s40478-020-00968-9

Schneider H, Weber CE, Schoeller J, Steinmann U, Borkowski J, Ishikawa H, Findeisen P, Adams O, Doerries R, Schwerk C, Schroten H, Tenenbaum T (2012): Chemotaxis of T-cells after infection of human choroid plexus papilloma cells with Echovirus 30 in an in vitro model of the blood-cerebrospinal fluid barrier. Virus Res. 170, 66-74 https://doi.org/10.1016/j.virusres.2012.08.019

Schneider-Hohendorf T, Rossaint J, Mohan H, Böning D, Breuer J, Kuhlmann T, Gross CC, Flanagan K, Sorokin L, Vestweber D, et al. (2014): VLA-4 blockade promotes differential routes into human CNS involving PSGL-1 rolling of T cells and MCAMadhesion of TH17 cells. J. Exp. Med. 211, 1833-1846 https://doi.org/10.1084/jem.20140540

Schwartz M, Baruch K (2012): Vaccine for the mind. Hum. Vaccin. Immunother. 8, 1465-1468 https://doi.org/10.4161/hv.21649

Schwerk C, Papandreou T, Schuhmann D, Nickol L, Borkowski J, Steinmann U, Quednau N, Stump C, Weiss C, Berger J, et al. (2012): Polar invasion and translocation of Neisseria meningitidis and Streptococcus suis in a novel human model of the blood-cerebrospinal fluid barrier. PLoS One 7, e30069 https://doi.org/10.1371/journal.pone.0030069

Schwerk C, Tenenbaum T, Kim KS, Schroten H (2015): The choroid plexus-a multi-role player during infectious diseases of the CNS. Front. Cell. Neurosci. 9, 80 https://doi.org/10.3389/fncel.2015.00080

Semba RD, Moghekar AR, Hu J, Sun K, Turner R, Ferrucci L, O’Brien $\mathrm{R}$ (2014): Klotho in the cerebrospinal fluid of adults with and without Alzheimer's disease. Neurosci. Lett. 558, 37-40 https://doi.org/10.1016/j.neulet.2013.10.058

Serot J-M, Foliguet B, Béné M-C, Faure G-C (1997): Ultrastructural and immunohistological evidence for dendritic-like cells within human choroid plexus epithelium. Neuroreport 8 https://doi.org/10.1097/00001756-199705260-00039

Serot J-M, Foliguet B, Béné MC, Faure GC (2001): Choroid plexus and ageing in rats: a morphometric and ultrastructural study. Eur. J. Neurosci. 14, 794-798 https://doi.org/10.1046/j.0953-816x.2001.01693.x

Shen MD (2018): Cerebrospinal fluid and the early brain development of autism. J. Neurodev. Disord. 10, 39 https://doi.org/10.1186/s11689-018-9256-7

Shuangshoti S, Roberts MP, Netsky MG (1965): Neuroepithelial (colloid) cysts: pathogenesis and relation to choroid plexus and ependyma. Arch. Pathol. 80, 214-224

Silva-Vargas V, Maldonado-Soto AR, Mizrak D, Codega P, Doetsch $\mathrm{F}$ (2016): Age-dependent niche signals from the choroid plexus regulate adult neural stem cells. Cell Stem Cell. 19, 643-652 https://doi.org/10.1016/j.stem.2016.06.013

Silverberg GD, Heit G, Huhn S, Jaffe RA, Chang SD, Bronte-Stewart H, Rubenstein E, Possin K, Saul TA (2001): The cerebrospinal 
fluid production rate is reduced in dementia of the Alzheimer's type. Neurology $\mathbf{5 7}, 1763$

https://doi.org/10.1212/WNL.57.10.1763

Silverberg GD, Miller MC, Messier AA, Majmudar S, Machan JT, Donahue JE, Stopa EG, Johanson CE (2010): Amyloid deposition and influx transporter expression at the bloodbrain barrier increase in normal aging. J. Neuropathol. Exp. Neurol. 69, 98-108 https://doi.org/10.1097/NEN.0b013e3181c8ad2f

Simen AA, Bordner KA, Martin MP, Moy LA, Barry LC (2011): Cognitive dysfunction with aging and the role of inflammation. Ther. Adv. Chronic Dis. 2, 175-195 https://doi.org/10.1177/2040622311399145

Simon MJ, Iliff JJ (2016): Regulation of cerebrospinal fluid (CSF) flow in neurodegenerative, neurovascular and neuroinflammatory disease. Biochim. Biophys. Acta 1862, 442-451 https://doi.org/10.1016/j.bbadis.2015.10.014

Smith AL (1987): Pathogenesis of Haemophilus influenzae meningitis. Pediatr. Infect. Dis. J. 6, 783-786 https://doi.org/10.1097/00006454-198708000-00037

Smith R, Myers K, Ravits J, Bowser R (2015): Amyotrophic lateral sclerosis: Is the spinal fluid pathway involved in seeding and spread? Med. Hypotheses 85, 576-583 https://doi.org/10.1016/j.mehy.2015.07.014

Smolek T, Madari A, Farbakova J, Kandrac O, Jadhav S, Cente M, Brezovakova V, Novak M, Zilka N (2016): Tau hyperphosphorylation in synaptosomes and neuroinflammation are associated with canine cognitive impairment. J. Comp. Neurol. 524, 874-895 https://doi.org/10.1002/cne.23877

Snow B, Mulroy E, Bok A, Simpson M, Smith A, Taylor K, Lockhart M, Lam BBJ, Frampton C, Schweder P, et al. (2019): A phase IIb, randomised, double-blind, placebo-controlled, dose-ranging investigation of the safety and efficacy of NTCELL [immunoprotected (alginate-encapsulated) porcine choroid plexus cells for xenotransplantation] in patients with Parkinson's disease. Parkinsonism Relat. Disord. 61, 88-93 https://doi.org/10.1016/j.parkreldis.2018.11.015

Solár P, Klusáková I, Jančálek R, Dubový P, Joukal M (2020a): Subarachnoid hemorrhage induces dynamic immune cell reactions in the choroid plexus. Front. Cell. Neurosci. 14, 18 https://doi.org/10.3389/fncel.2020.00018

Solár P, Zamani A, Kubíčková L, Dubový P, Joukal M (2020b): Choroid plexus and the blood-cerebrospinal fluid barrier in disease. Fluids Barriers CNS 17, 35 https://doi.org/10.1186/s12987-020-00196-2

Speake T, Freeman LJ, Brown PD (2003): Expression of aquaporin 1 and aquaporin 4 water channels in rat choroid plexus. Biochim. Biophys. Acta 1609, 80-86 https://doi.org/10.1016/S0005-2736(02)00658-2

Spector R, Keep RF, Robert Snodgrass S, Smith QR, Johanson CE (2015): A balanced view of choroid plexus structure and function: Focus on adult humans. Exp. Neurol. 267, 78-86 https://doi.org/10.1016/j.expneurol.2015.02.032

Staats JJ, Feder I, Okwumabua O, Chengappa MM (1997): Streptococcus suis: past and present. Vet. Res. Commun. 21, 381-407 https://doi.org/10.1023/A:1005870317757
Steinemann A, Galm I, Chip S, Nitsch C, Maly IP (2016): Claudin-1, -2 and -3 are selectively expressed in the epithelia of the choroid plexus of the mouse from early development and into adulthood while Claudin-5 is restricted to endothelial cells. Front. Neuroanat. 10, 16 https://doi.org/10.3389/fnana.2016.00016

Stopa EG, Tanis KQ, Miller MC, Nikonova EV, Podtelezhnikov AA, Finney EM, Stone DJ, Camargo LM, Parker L, Verma A, et al. (2018): Comparative transcriptomics of choroid plexus in Alzheimer's disease, frontotemporal dementia and Huntington's disease: implications for CSF homeostasis. Fluids Barriers CNS 15, 18 https://doi.org/10.1186/s12987-018-0102-9

Strominger I, Elyahu Y, Berner O, Reckhow J, Mittal K, Nemirovsky A, Monsonego A (2018): The choroid plexus functions as a niche for T-cell stimulation within the central nervous system. Front. Immunol. 9, 1066 https://doi.org/10.3389/fimmu.2018.01066

Sweeney MD, Sagare AP, Zlokovic BV (2018): Blood-brain barrier breakdown in Alzheimer disease and other neurodegenerative disorders. Nat. Rev. Neurol. 14, 133-150 https://doi.org/10.1038/nrneurol.2017.188

Swiderski RE, Agassandian K, Ross JL, Bugge K, Cassell MD, Yeaman C (2012): Structural defects in cilia of the choroid plexus, subfornical organ and ventricular ependyma are associated with ventriculomegaly. Fluids Barriers CNS 9, 22

https://doi.org/10.1186/2045-8118-9-22

Tarkowski E, Andreasen N, Tarkowski A, Blennow K (2003): Intrathecal inflammation precedes development of Alzheimer's disease. J. Neurol. Neurosurg. Psychiatry 74, 1200-1205 https://doi.org/10.1136/jnnp.74.9.1200

Thanos CG, Bintz B, Emerich DF (2010): Microencapsulated choroid plexus epithelial cell transplants for repair of the brain. In: Therapeutic Applications of Cell Microencapsulation (Eds. Pedraz JL, Orive G), pp 80-91, Springer, New York https://doi.org/10.1007/978-1-4419-5786-3_8

Tietz S, Engelhardt B (2015): Brain barriers: Crosstalk between complex tight junctions and adherens junctions. J. Cell Biol. 209, 493-506

https://doi.org/10.1083/jcb.201412147

Tirapelli DP, Lopes Lda S, Lachat JJ, Colli BO, Tirapelli LF (2007): Ultrastructural study of the lateral ventricle choroid plexus in experimental hydrocephalus in Wistar rats. Arq. Neuropsiquiatr. 65, 974-977 https://doi.org/10.1590/S0004-282X2007000600010

Tissir F, Qu Y, Montcouquiol M, Zhou L, Komatsu K, Shi D, Fujimori T, Labeau J, Tyteca D, Courtoy P, et al. (2010): Lack of cadherins Celsr2 and Celsr3 impairs ependymal ciliogenesis, leading to fatal hydrocephalus. Nat. Neurosci. 13, 700-707 https://doi.org/10.1038/nn.2555

Tseng H-K, Huang T-Y, Wu AY-J, Chen H-H, Liu C-P, Jong A (2015): How Cryptococcus interacts with the blood-brain barrier. Future Microbiol. 10, 1669-1682 https://doi.org/10.2217/fmb.15.83

Van Cauwenberghe C, Gorlé N, Vandenbroucke RE (2020): Roles of the choroid plexus in aging. In: Role of the Choroid Plexus in Health and Disease (Eds. Praetorius J, Blazer-Yost B, Damkier H), pp 209-232, Springer US, New York https://doi.org/10.1007/978-1-0716-0536-3_9 
van Loo KM, Martens GJ (2007): Genetic and environmental factors in complex neurodevelopmental disorders. Curr. Genomics 8, 429-444 https://doi.org/10.2174/138920207783591717

Vandenbroucke RE, Dejonckheere E, Van Lint P, Demeestere D, Van Wonterghem E, Vanlaere I, Puimege L, Van Hauwermeiren F, De Rycke R, Mc Guire C, et al. (2012): Matrix metalloprotease 8-dependent extracellular matrix cleavage at the blood-CSF barrier contributes to lethality during systemic inflammatory diseases. J. Neurosci. 32, 9805-9816 https://doi.org/10.1523/JNEUROSCI.0967-12.2012

Vercellino M, Votta B, Condello C, Piacentino C, Romagnolo A, Merola A, Capello E, Mancardi GL, Mutani R, Giordana MT, Cavalla P (2008): Involvement of the choroid plexus in multiple sclerosis autoimmune inflammation: a neuropathological study. J. Neuroimmunol. 199, 133-141 https://doi.org/10.1016/j.jneuroim.2008.04.035

Vercellino M, Masera S, Lorenzatti M, Condello C, Merola A, Mattioda A, Tribolo A, Capello E, Mancardi GL, Mutani R, et al. (2009): Demyelination, inflammation, and neurodegeneration in multiple sclerosis deep gray matter. J. Neuropathol. Exp. Neurol. 68, 489-502 https://doi.org/10.1097/NEN.0b013e3181a19a5a

Verkhratsky A, Nedergaard M, Hertz L (2015): Why are astrocytes important? Neurochem. Res. 40, 389-401 https://doi.org/10.1007/s11064-014-1403-2

Warf BC (2005): Comparison of endoscopic third ventriculostomy alone and combined with choroid plexus cauterization in infants younger than 1 year of age: a prospective study in 550 African children. J. Neurosurg. 103, 475-481 https://doi.org/10.3171/ped.2005.103.6.0475

Warf BC (2013): Educate one to save a few. Educate a few to save many. World Neurosurg. 79, 15-18 https://doi.org/10.1016/j.wneu.2010.09.021

Wen GY, Wisniewski HM, Kascsak RJ (1999): Biondi ring tangles in the choroid plexus of Alzheimer's disease and normal aging brains: a quantitative study. Brain Res. 832, 40-46 https://doi.org/10.1016/S0006-8993(99)01466-3

West MJ, Coleman PD, Flood DG, Troncoso JC (1997): Is Alzheimer's disease accelerated aging? Different patterns of age and Alzheimer's disease-related neuronal losses in the hippocampus. In: Connections, Cognition and Alzheimer's Disease. Research and Perspectives in Alzheimer's Disease (Eds. Hayman BT, Duyckae RC, Christen Y), Springer, Berlin, Heidelberg https://doi.org/10.1007/978-3-642-60680-9_10

Wewer C, Seibt A, Wolburg H, Greune L, Schmidt MA, Berger J, Galla HJ, Quitsch U, Schwerk C, Schroten H, Tenenbaum T (2011): Transcellular migration of neutrophil granulocytes through the blood-cerebrospinal fluid barrier after infection with Streptococcus suis. J. Neuroinflammation 8, 51 https://doi.org/10.1186/1742-2094-8-51

Williams AE, Blakemore WF (1990): Pathogenesis of meningitis caused by streptococcus suis type 2. J. Infect. Dis. 162, 474-481 https://doi.org/10.1093/infdis/162.2.474

Wodarczyk C, Rowe I, Chiaravalli M, Pema M, Qian F, Boletta A (2009): A novel mouse model reveals that polycystin-1 deficiency in ependyma and choroid plexus results in dysfunctional cilia and hydrocephalus. PLoS One 4, e7137 https://doi.org/10.1371/journal.pone.0007137

Wolburg H, Mogk S, Acker S, Frey C, Meinert M, Schönfeld C, Lazarus M, Urade Y, Kubata BK, Duszenko M (2012): Late stage infection in sleeping sickness. PLoS One 7, e34304 https://doi.org/10.1371/journal.pone.0034304

Wolburg H, Paulus W (2010): Choroid plexus: biology and pathology. Acta Neuropathol. 119, 75-88 https://doi.org/10.1007/s00401-009-0627-8

Wolburg H, Wolburg-Buchholz K, Liebner S, Engelhardt B (2001): Claudin-1, claudin-2 and claudin-11 are present in tight junctions of choroid plexus epithelium of the mouse. Neurosci. Lett. 307, 77-80 https://doi.org/10.1016/S0304-3940(01)01927-9

Wu XH, Pang YX, Qiu HY, Chen JP, Zhang QL, Niu Q (2016): Effects of subchronic aluminum lactate exposure on learning and memory and transportation of $A \beta$ in blood-cerebrospinal fluid in rats. Zhonghua Lao Dong Wei Sheng Zhi Ye Bing Za Zhi 34, 90-94

Yang J, Simonneau C, Kilker R, Oakley L, Byrne MD, Nichtova Z, Stefanescu I, Pardeep-Kumar F, Tripathi S, Londin E, et al. (2019): Murine MPDZ-linked hydrocephalus is caused by hyperpermeability of the choroid plexus. EMBO Mol. Med. 11, e9540 https://doi.org/10.15252/emmm.201809540

Yang Y, Estrada EY, Thompson JF, Liu W, Rosenberg GA (2007): Matrix metalloproteinase-mediated disruption of tight junction proteins in cerebral vessels is reversed by synthetic matrix metalloproteinase inhibitor in focal ischemia in rat. J. Cereb. Blood Flow Metab. 27, 697-709 https://doi.org/10.1038/sj.jcbfm.9600375

Zeng C-Y, Yang T-T, Zhou H-J, Zhao Y, Kuang X, Duan W, Du J-R (2019): Lentiviral vector-mediated overexpression of Klotho in the brain improves Alzheimer's disease-like pathology and cognitive deficits in mice. Neurobiol. Aging 78, 18-28 https://doi.org/10.1016/j.neurobiolaging.2019.02.003

Zeni P, Doepker E, Topphoff US, Huewel S, Tenenbaum T, Galla H-J (2007): MMPs contribute to TNF- $\alpha$-induced alteration of the blood-cerebrospinal fluid barrier in vitro. Am. J. Physiol. 293, C855-C864

https://doi.org/10.1152/ajpcell.00470.2006

Zhan X, Stamova B, Sharp FR (2018): Lipopolysaccharide associates with amyloid plaques, neurons and oligodendrocytes in Alzheimer's disease brain: a review. Front. Aging Neurosci. 10, 42 https://doi.org/10.3389/fnagi.2018.00042

Zhou G, Hotta J, Lehtinen MK, Forss N, Hari R (2015): Enlargement of choroid plexus in complex regional pain syndrome. Sci. Rep. 5, 14329 https://doi.org/10.1038/srep14329

Zhou Y-F, Huang J-C, Zhang P, Fan F-M, Chen S, Fan H-Z, Cui Y-M, Luo X-G, Tan S-P, Wang Z-R, et al. (2020): Choroid plexus enlargement and allostatic load in schizophrenia. Schizophr. Bull. 46, 722-731

https://doi.org/10.1093/schbul/sbz100

Zilka N, Kazmerova Z, Jadhav S, Neradil P, Madari A, Obetkova D, Bugos O, Novak M (2012): Who fans the flames of Alzheimer's disease brains? Misfolded tau on the crossroad of neurodegenerative and inflammatory pathways. J. Neuroinflammation 9, 47 
https://doi.org/10.1186/1742-2094-9-47

Zlokovic BV, Martel CL, Matsubara E, McComb JG, Zheng G, McCluskey RT, Frangione B, Ghiso J (1996): Glycoprotein 330/megalin: probable role in receptor-mediated transport of apolipoprotein J alone and in a complex with Alzheimer disease amyloid beta at the blood-brain and blood-cerebrospinal fluid barriers. Proc. Natl. Acad. Sci. USA 93, 4229 https://doi.org/10.1073/pnas.93.9.4229

Zlokovic BV (2008): The blood-brain barrier in health and chronic neurodegenerative disorders. Neuron 57, 178-201

https://doi.org/10.1016/j.neuron.2008.01.003

Received: June 4, 2021

Final version accepted: July 30, 2021 